Article

\title{
Several Human Cyclin-Dependent Kinase Inhibitors, Structurally Related to Roscovitine, As New Anti-Malarial Agents
}

\author{
Sandrine Houzé ${ }^{1}$, Nha-Thu Hoang ${ }^{2}$, Olivier Lozach ${ }^{3}$, Jacques Le Bras ${ }^{1}$, Laurent Meijer ${ }^{3,4}$, \\ Hervé Galons ${ }^{4,5}$ and Luc Demange ${ }^{2,6, *}$
}

1 Laboratoire de Parasitologie, CNR du Paludisme, AP-HP, Hôpital Bichat \& UMR 216 IRD, Université Paris Descartes, Sorbonne Paris Cité, UFR des Sciences Pharmaceutiques, 4 avenue de l'Observatoire, Paris 75006, France; E-Mails: sandrine.houze@bch.aphp.fr (S.H.); jacques.lebras@bch.aphp.fr (J.L.B.)

2 Laboratoire de Chimie et Biochimie Pharmacologiques et Toxicologiques (LCBPT), UMR 8601 CNRS, Université Paris Descartes, Sorbonne Paris Cité, UFR Biomédicale des Saints Pères, 45 rue des Saints-Pères, Paris 75270, France; E-Mail: luc.demange@parisdescartes.fr

3 Protein Phosphorylation and Human Diseases Group, CNRS, USR 3151, Station biologique, Roscoff 29680, France; E-Mails: olivier.lozach@sb-roscoff.fr (O.L.); meijer@sb-roscoff.fr (L.M.)

4 ManRos Therapeutics, Hôtel de Recherche, Centre de Perharidy, Roscoff 29680, France; E-Mail: herve.galons@parisdescartes.fr

5 Laboratoire de Pharmacochimie, INSERM U 1022, Université Paris Descartes, Sorbonne Paris Cité, UFR des Sciences Pharmaceutiques, 4 avenue de l'Observatoire, Paris 75006, France

6 Institut de Chimie de Nice (ICN), UMR 7272 CNRS, Université de Nice Sophia-Antipolis, Parc Valrose, Nice 06108, France

* Author to whom correspondence should be addressed; E-Mail: luc.demange@parisdescartes.fr; Tel.: +33-(0)4-92-07-65-96; Fax: +33-(0)4-92-07-61-25.

Received: 31 July 2014; in revised form: 8 September 2014 / Accepted: 11 September 2014 / Published: 23 September 2014

\begin{abstract}
In Africa, malaria kills one child each minute. It is also responsible for about one million deaths worldwide each year. Plasmodium falciparum, is the protozoan responsible for the most lethal form of the disease, with resistance developing against the available anti-malarial drugs. Among newly proposed anti-malaria targets, are the $P$. falciparum cyclin-dependent kinases (PfCDKs). There are involved in different stages of the protozoan growth and development but share high sequence homology with human cyclin-dependent kinases (CDKs). We previously reported the synthesis of CDKs inhibitors that are structurally-related to $(R)$-roscovitine, a 2,6,9-trisubstituted purine, and they
\end{abstract}


showed activity against neuronal diseases and cancers. In this report, we describe the synthesis and the characterization of new CDK inhibitors, active in reducing the in vitro growth of $P$. falciparum (3D7 and 7G8 strains). Six compounds are more potent inhibitors than roscovitine, and three exhibited $\mathrm{IC}_{50}$ values close to $1 \mu \mathrm{M}$ for both 3D7 and 7G8 strains. Although, such molecules do inhibit $P$. falciparum growth, they require further studies to improve their selectivity for PfCDKs.

Keywords: Plasmodium falciparum; cyclin-dependent kinases CDKs; PfCDKs; 2,6,9-trisubstituted purines; roscovitine; Buchwald-Hartwig amination

\section{Introduction}

Malaria remains today one of the most devastating infectious diseases in the world. Despite remarkable progress in the global fight against malaria, this deadly protozoan infection takes an estimated 700,000 lives per year, mostly African children under five years of age [1].

Among the different species of protozoan parasites responsible for malaria, Plasmodium falciparum, which is transmitted to humans through the bite of infected Anopheles mosquitoes, is the most lethal [2]. Current treatments effective for malaria include chloroquine, mefloquine and artemisinin, but these drugs becoming less effective due to the gradual emergence of drug-resistant strains [3]. Artemisinin-based combination therapies have been adopted as the first-line antimalarial agents of choice against these resistant Plasmodium parasites. Recently, however, there has been increasing concern regarding the development of resistance to the artemisinins further emphasizing the need for new antimalarial agents with different mechanisms of action [4]. As a consequence of the resistance, an alarming resurgence of malaria has occurred, and the anti-malarial drug space should be urgently extended. New targets, such as the apicoplast [5], the protozoan proteases [6], or the specific mitochondrial electron transport chain are currently being investigated [7]. Protein kinases, which regulate protozoan growth and differentiation during its life cycle, have also emerged to be among the most promising new anti-malarial targets [8-11]. A short survey of the recent literature highlights the success of targeting $P$. falciparum kinases such as thymidinate kinase $\left(\mathrm{K}_{\mathrm{I}}=20 \mu \mathrm{M}\right)$ [12], cGMP-dependent protein kinase $\left(\mathrm{IC}_{50}=8 \mathrm{nM}\right)$ [13], calcium-dependent kinase 1 ( $\mathrm{IC}_{50}$ in the $10-20 \mathrm{nM}$ range) [14,15], and PfRIO-2 kinase, which regulates the plasmodial ribosome biogenesis [16].

Among the human kinome, the cyclin-dependent kinases (CDKs) constitute a family of 20 ubiquitous serine/threonine kinases [17-19]. They are mainly involved in cell-cycle regulation [20,21], apoptosis [22] and gene transcription [23]. Importantly, regulatory proteins called cyclins form dimeric structures with the CDKs and are therefore responsible for their activation [17]. In humans, CDKs deregulation is involved in severe pathologies such as cancers (solid tumors and leukemias) [18], neuronal disorders (including Alzheimer's and Parkinson's diseases) [24,25] and type 2 diabetes [26]. Indeed, CDKs are considered as promising therapeutic targets in a wide range of pathologies including viral infections (AIDS), renal diseases (glomerulonephritis and polycystic kidney disease), inflammation and cardio-vascular diseases [27]. 
A family of $P$. falciparum kinases, PfCDKs, which share high sequence homology with human CDKs, were identified in the 1990s. Thus, PfPK5 (around $60 \%$ of sequence identity with human CDK1 and CDK5) [28], PfPK6 (57\% similarity with the catalytic domain of CDK2) [29], and Pfmrk (46\% of sequence identity with CDK7) [30] have been extensively studied and characterized. Interestingly, CDKs and PfCDKs exhibit similar activation by phosphorylation, catalyzed by CDK activating kinases [28], and interaction with endogenous inhibitors, such as $\mathrm{p} 21^{\mathrm{CIP} 1}$ [31]. Moreover, PfCDKs co-incubation with human cyclins leads to their functional activation [32]. Despite these strong molecular and functional homologies, HsCDKs and PfCDK have structurally diverged to allow selective targeting the $P f C D K s$ without affecting host CDKs. Indeed, many known CDKs inhibitors are unable to inhibit PfCDKs [9-12,33-38].

The purine scaffold is widely used for the development of therapeutic agents $[39,40]$, and it has therefore provided several CDKs inhibitors such as $(R)$-roscovitine (1) or purvalanol A (2a) and B (2b) (Figure 1) [41]. Basically, $(R)$-roscovitine, a 2,6,9-trisubstituted purine, is a very promising molecule developed by Cyclacel Pharmaceuticals which reached phases 2 and $2 \mathrm{~b}$ clinical trials against different types of cancers, and phase 1 clinical trial against glomerulonephritis. Interestingly, the $(R)$-roscovitine clinical trials pointed out the low cytotoxicity of this molecule. To summarize, a daily oral dose of $2 \mathrm{~g}$ was found as the maximal tolerated dose in human. Pharmacokinetics studies showed a rapid elimination of this drug with a half-life between 60 and $90 \mathrm{~min}$. In humans, following oral administration, $(R)$-roscovitine offers good oral bioavailability and undergoes a rapid passage into the blood, distribution in tissues, and metabolism. Altogether, these results suggest that oral administration is possible for extended periods of treatment [41].

Figure 1. Chemical structures of some purine CDK inhibitors.

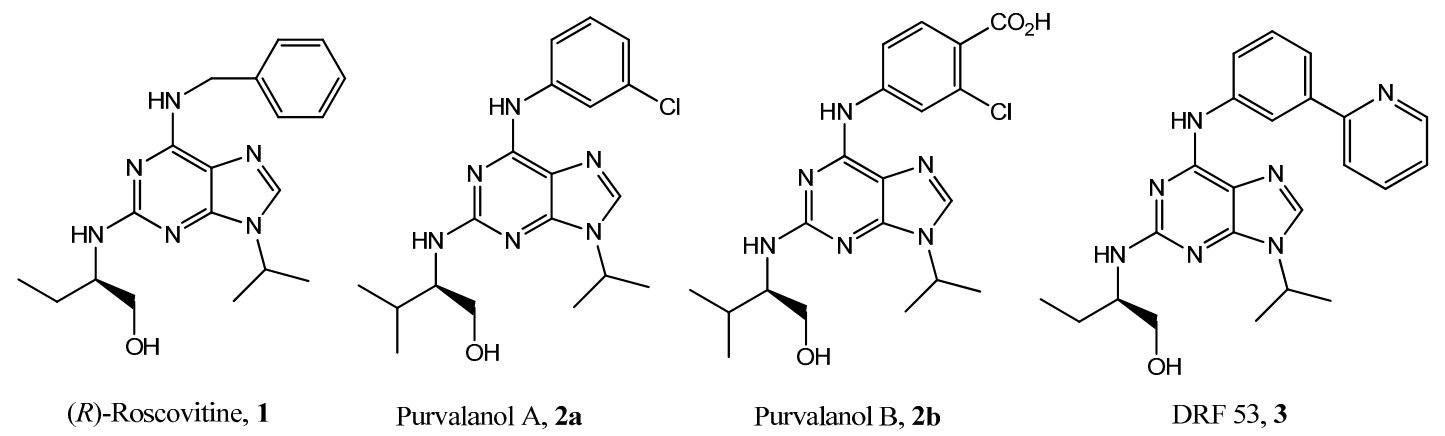

This molecule binds CDKs in the ATP pocket and is rather selective for CDK1, CDK2, CDK5, CDK7 and CDK9, but interacts with other kinases although with lower affinity (e.g., casein kinase 1 (CK1), dual specificity, tyrosine phosphorylation regulated kinases (DYRKs), pyridoxal kinase) [42,43].

In this context, our team focused its efforts on the identification of new CDK inhibitors structurally-related to $(R)$-roscovitine [44]. Thus, by means of innovative Buchwald-Hartwig aminations and Suzuki cross-coupling reactions, we developed several series of 2,6,9-trisubstituted purines including 6-aminoaryl, 6-aminoheteroaryl and 6-aminobiaryl moieties [45,46]. Biological characterization of these molecules revealed "hit" compounds such as DRF053 (3), one of the most potent CK1 inhibitor $\left(\mathrm{IC}_{50}=14 \mathrm{nM}\right)$ and $\mathrm{CDK} 5$ inhibitor $\left(\mathrm{IC}_{50}=80 \mathrm{nM}\right)$, which antagonizes amyloïd- $\beta$ production in the N2A-APP659 cell model, in a dose-dependent manner [44]. In addition, introduction of 
6-aminoheteroaryl moieties leads to inhibitors which are 5- to 10-fold more potent than $(R)$-roscovitine in cytotoxicity assays on human neuroblastoma SH-SY5Y cells (IC50 ranging from 1.8 $\mu \mathrm{M}$ to $2.1 \mu \mathrm{M}$ ) [45].

In the present paper, we report the synthesis of a new series of 2,6,9-trisubstituted purines structurally-related to $(R)$-roscovitine, and bearing amino-heterocyclic motives in the $\mathrm{C}^{2}$ purine ring, such as 2-aminopyrimidine (4a-d) and 5-aminopyrimidine (5) mimicking the pyrimidine core found in the anti-cancer drug imatinib (Gleevec ${ }^{\circledR}$ ), and an aminopyrazine (6) (Figure 2). In addition, we report the characterization of new 2,6,9-trisubstituted purines belonging to previously reported series of HsCDKs inhibitors. All these molecules were evaluated against a panel of human kinases including CDK1, CDK2, CDK5, glycogen synthase kinase-3 (GSK-3), CK1 and DYRK1A. Finally, these newly-synthesized molecules and several other compounds belonging to our library of purines were screened as potential growth inhibitors of $P$. falciparum.

Figure 2. General structure for the newly-synthesized compounds.
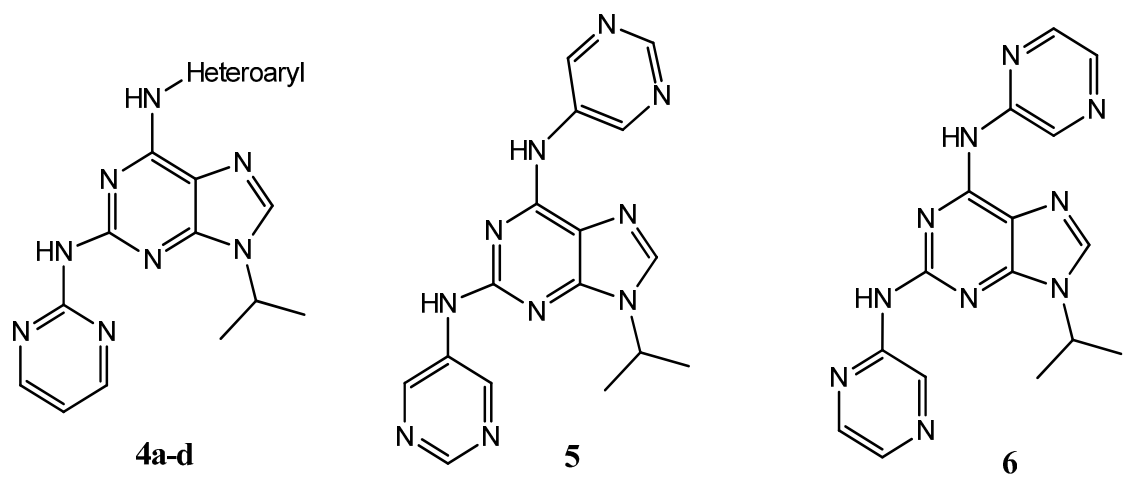

\section{Results and Discussion}

\subsection{Chemical Synthesis}

\subsubsection{Synthesis of New Purines Series Bearing $C^{2}$ Amino-Heterocyclic Moities}

Compounds 4a-d were synthesized following an efficient three-step procedure outlined in Scheme 1. Briefly, the commercially available 2-amino-6-chloropurine was regioselectively converted into 2-amino-6-chloro-9-iso-propylpurine (7) in 70\% yield using 2-bromopropane at $15-18{ }^{\circ} \mathrm{C}$ in DMSO for 5 days. Then, compound 7 was reacted with 2-bromopyrimidine under the palladium catalysis Buchwald-Hartwig amination conditions we previously reported $(\mathrm{Pd}(\mathrm{OAc}) 2,10 \%$; BINAP 10\%, $\mathrm{KOtBu}, 1.5$ eq.) to afford 6-chloro-9-isopropyl- $N$-(pyrimidin-2-yl)-2-aminopurine (8) in $85 \%$ yield [47]. A second amination gave the final compounds $4 \mathbf{a}-\mathbf{c}$ with $70 \%-80 \%$ yield. Lower amount of catalyst and ligand $\left(\mathrm{Pd}(\mathrm{OAc})_{2}, 4 \%\right.$; BINAP 6\%, tBuOK, 1.5 eq.) were required for this second Buchwald-Hartwig amination to avoid polysubstitution on the purine scaffold $[45,48]$.

We already reported the formation of compounds $\mathbf{5}$ and $\mathbf{6}$ as side products from a Buchwald-Hartwig amination on the 2,6-dichloro-9-isopropylpurine (9), obtained through a region selective $\mathrm{N}^{9}$ alkylation with the commercially available 2,6-dichloropurine [45]. 
Scheme 1. Synthetic route to compounds $\mathbf{4 a}-\mathbf{d}$.

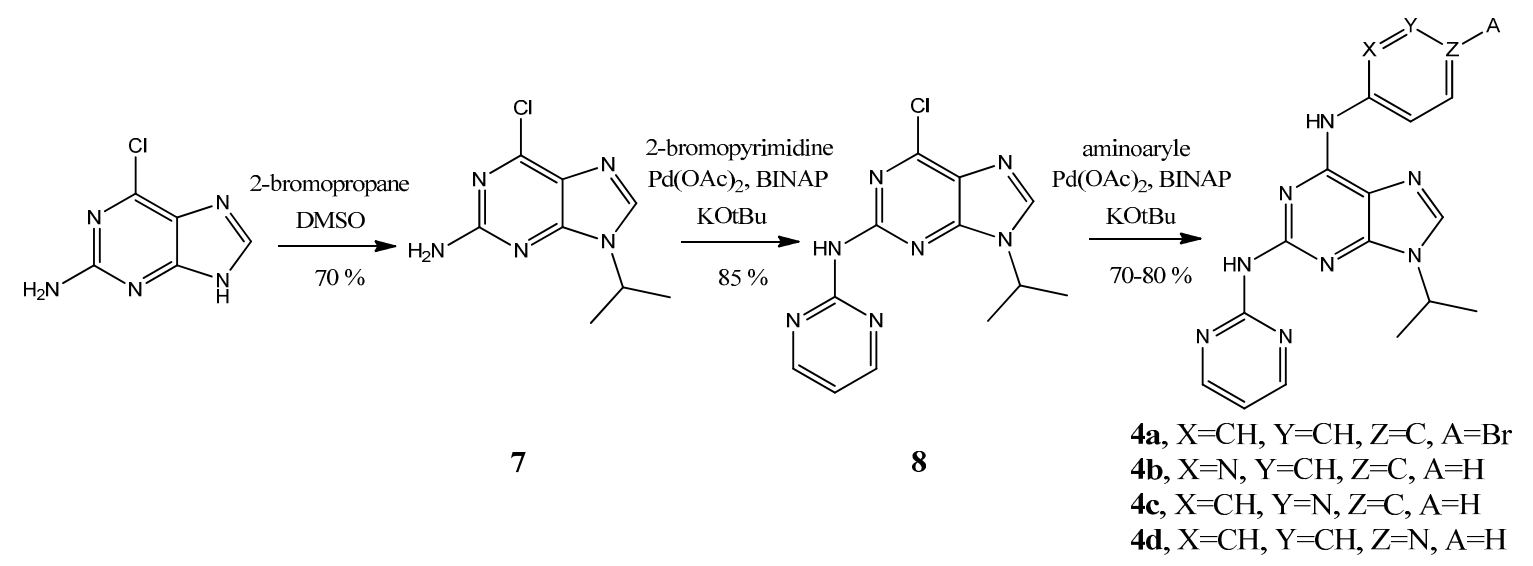

We report here the optimization of this catalytic system in order to obtain exclusively this di-amination product in good yield. As shown in Scheme 2, we used aminopyrazine as a nucleophile for this optimization, and our study revealed that the use of $8 \%$ of $\mathrm{Pd}(\mathrm{OAc})_{2}$ pre-catalyst and $16 \%$ of racemic BINAP ligand gave compound 6 with the highest conversion rate. In contrast to our previous study on amination with aminopyridines, we do not observe here the formation of a triarylamine product based upon the aminopyridazine scaffold [47]. Surprisingly, the replacement of the $\operatorname{Pd}(\mathrm{II})$ pre-catalyst by a $\mathrm{Pd}(0)$ pre-catalyst $\left(\mathrm{Pd}_{2} \mathrm{dba}_{3}\right)$ leads only to decomposition products. Finally the use of the $\mathrm{Pd}(\mathrm{OAc})_{2}$ catalytic system allowed the formation of compound 5 in $70 \%$ yield (Scheme 2 ).

Scheme 2. Synthetic route to compounds 5 and $\mathbf{6}$ and Buchwald-Hartwig diamination optimization.
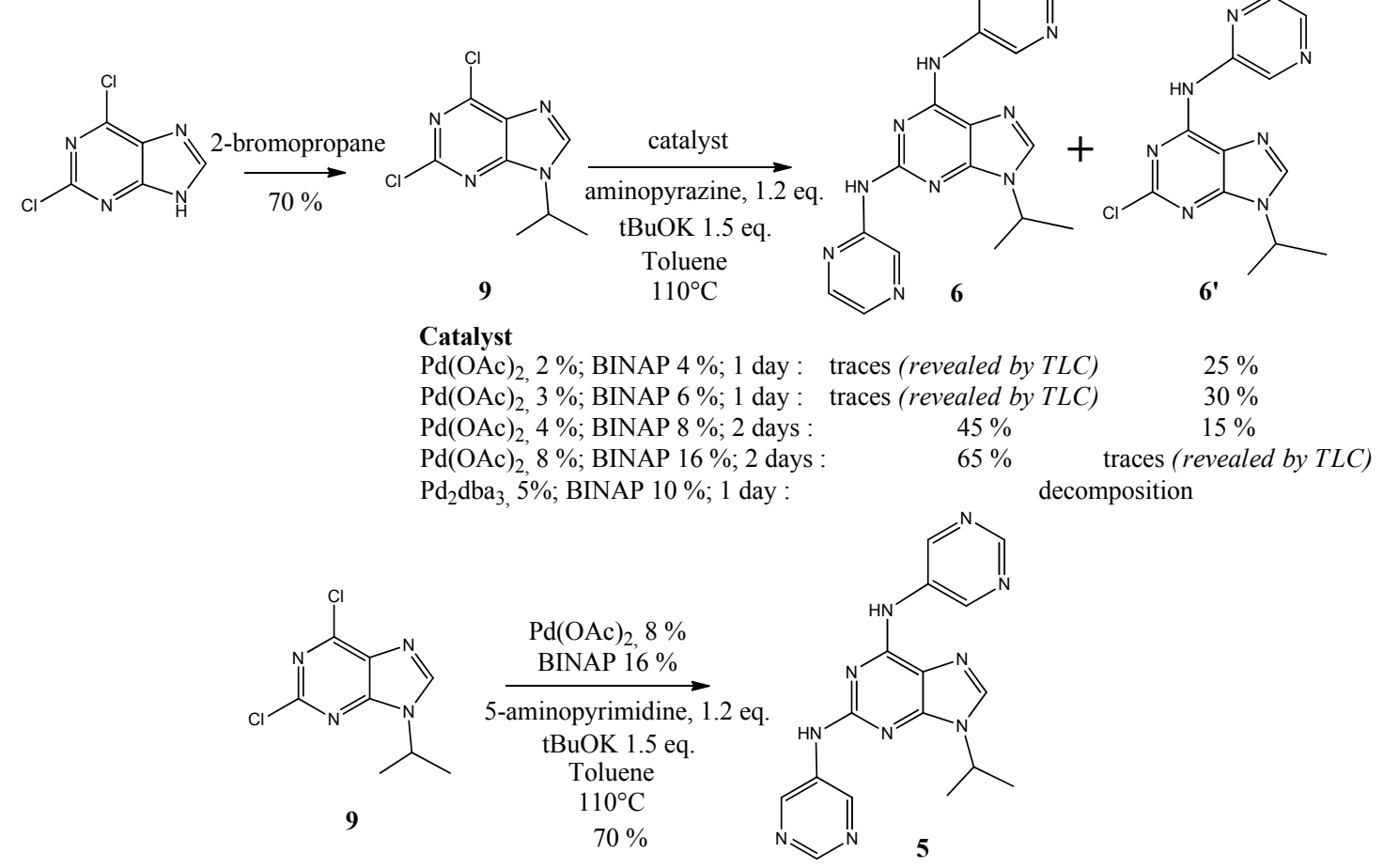


\subsubsection{Synthesis of New 6-Aminobiaryl Molecules Structurally-Related to $(R)$-Roscovitine}

To complete our purine library with compounds structurally-related to $(R)$-roscovitine, we synthesized compounds 10-13 according to previously reported synthesis routes, whose key steps are Buchwald-Hartwig aminations and Suzuki cross-coupling reactions (Scheme 3) [44,47].

Scheme 3. Synthesis of new 6-aminobiaryle 10-13.

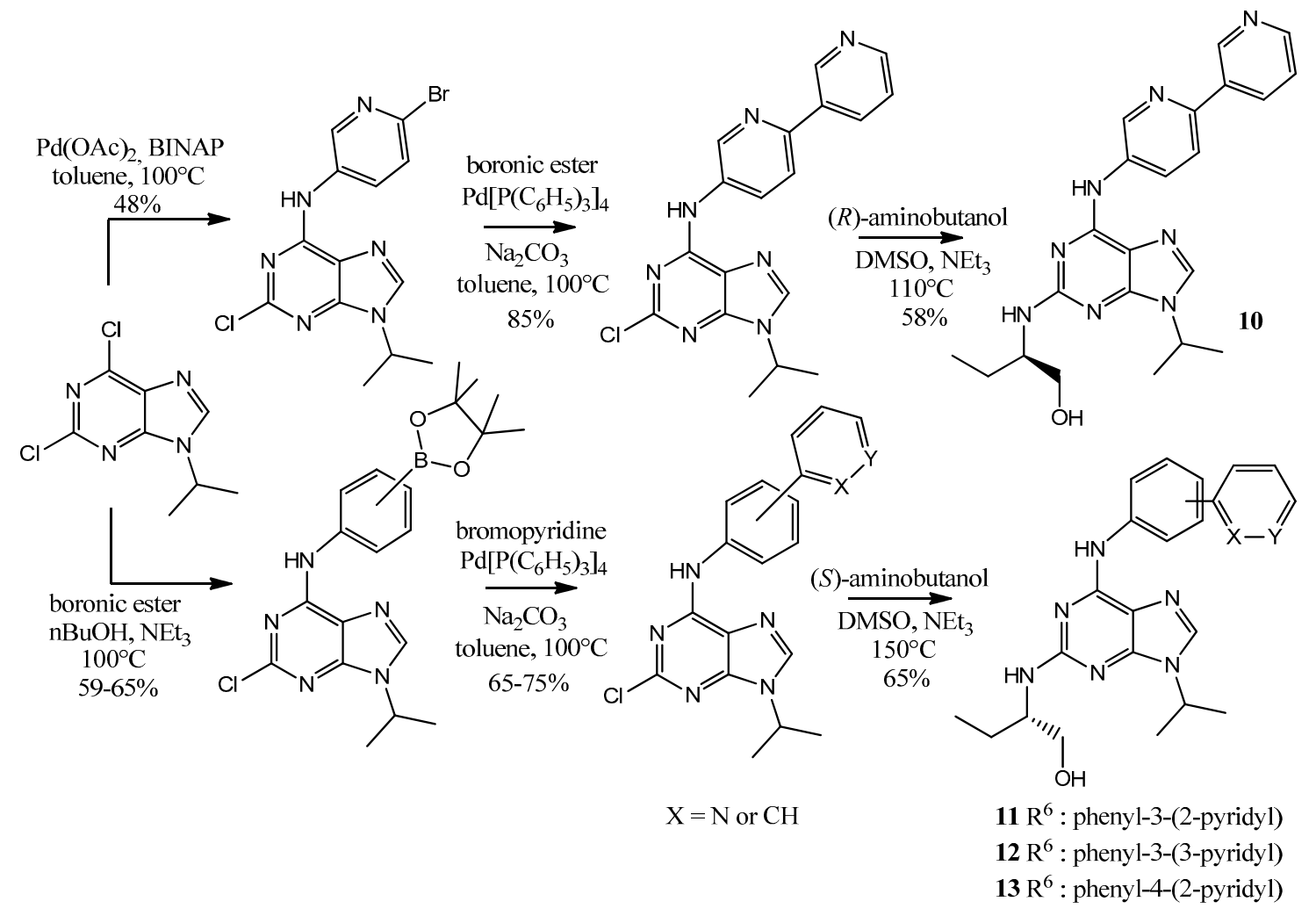

\subsection{Molecular Assays on Mammalian Kinases}

All newly synthesized compounds were tested as potential inhibitors on a panel of several mammalian kinases. The effects on CDK1/cyclin B, CDK2/cyclin A, CDK5/p25, GSK-3 $\alpha \beta$, CK1 $\delta / \varepsilon$ and DYRK1A kinase activity are reported as the $\mathrm{IC}_{50}$ values calculated from dose-response curves. They are summarized in Table 1. The inhibition was determined covering a range of concentrations of the compounds by means of a $\left[\gamma_{-}{ }^{33} \mathrm{P}\right]$ assay as described in the experimental section.

Globally, compounds $\mathbf{4 a - d}$, with a 2-aminopyrimidine in the $\mathrm{C}^{2}$ position, and compound $\mathbf{6}$ with a 2-aminopyrazine in the $\mathrm{C}^{2}$ position, are poor kinase inhibitors when compared to $(R)$-roscovitine (1) or DRF053 (3). Moreover, we recently reported that $4 \mathbf{a}-\mathbf{d}$ analogs bearing an aminoalcohol in the purine $\mathrm{C}^{2}$ position inhibits $\mathrm{CDKs}$ with $\mathrm{IC}_{50}$ values ranging from $0.01 \mu \mathrm{M}$ to $1.00 \mu \mathrm{M}$. Altogether, these results underline the relevance of the $\mathrm{C}^{2}$ aminoalcohol to improve the CDKs ATP-pocket binding, since the hydroxyl group of the amino-alcohol is engaged in a H-bonding network involving water molecules. Therefore this hydroxyl group plays a critical role for improved inhibitor binding [49,50]. 
Table 1. Newly-synthesized trisubstituted purines effects on several mammalian protein kinases activity. Purine derivatives were tested at various concentrations as described in the experimental section; IC50 values are provided in $\mu \mathrm{M}$ were estimated, dose-response curves and are expressed in $\mu \mathrm{M}$. All assays were run in triplicates and data points were within less than a $10 \%$ range.

\begin{tabular}{ccccccc}
\hline \multirow{2}{*}{ Compounds } & \multicolumn{7}{c}{ IC $_{\mathbf{5 0}}(\boldsymbol{\mu M M})^{\mathbf{a}}$} \\
\cline { 2 - 7 } & $\mathbf{C D K 1}$ & $\mathbf{C D K 2}$ & $\mathbf{C D K 5}$ & $\mathbf{G S K - 3 \alpha \boldsymbol { \beta }}$ & $\mathbf{C K 1 \delta / \varepsilon}$ & DYRK1A \\
\hline $\mathbf{1}$ & 0.35 & 0.70 & 0.2 & N.I. & 2.3 & - \\
$\mathbf{3}$ & 0.22 & - & 0.08 & $>10$ & 0.01 & - \\
$\mathbf{4 a}$ & - & - & 1.0 & 1.0 & 1.0 & 3.0 \\
$\mathbf{4 b}$ & 12 & - & $>10$ & $>10$ & $>10$ & 8 \\
$\mathbf{4 c}$ & 3.0 & 1.8 & 4.3 & $>10$ & $>10$ & 8 \\
$\mathbf{4 d}$ & 9.3 & - & 7.0 & $>10$ & 2.8 & 5.2 \\
$\mathbf{5}$ & - & 0.2 & 0.4 & $>10$ & 0.2 & 0.5 \\
$\mathbf{6}$ & - & 2.8 & 13 & $>10$ & 1.1 & 0.5 \\
$\mathbf{1 0}$ & 0.01 & - & 0.03 & $>10$ & 0.2 & - \\
$\mathbf{1 1}$ & 0.8 & - & 0.4 & $>10$ & 0.04 & - \\
$\mathbf{1 2}$ & 0.2 & - & 0.1 & $>10$ & 0.2 & - \\
$\mathbf{1 3}$ & 0.2 & 0.2 & - & $>10$ & 0.5 & - \\
\hline
\end{tabular}

${ }^{a} \mathrm{IC}_{50}$ value reported as $>10$ indicates that the compound display no activity at the highest concentration tested $(10 \mu \mathrm{M})$; -: not tested.

The influence of the amino-alcohol stereochemistry on the kinase inhibition appeared to be limited. Nevertheless, as reported on several series of 2,6,9-trisubstituted purines including $(R)$-roscovitine itself, the $(R)$ stereoisomer showed a higher affinity for CDK than the $(S)$ one. This might be highlighted on CDK5 by comparing $11\left(\mathrm{IC}_{50}=0.4 \mu \mathrm{M}\right)$ and $12\left(\mathrm{IC}_{50}=0.1 \mu \mathrm{M}\right)$ with their corresponding $(R)$ stereoisomers ( $\mathrm{IC}_{50}=0.08 \mu \mathrm{M}$ and $\mathrm{IC}_{50}=0.05 \mu \mathrm{M}$, respectively [44]).

As expected, compound 10 is a potent $\mathrm{CDK} 5$ inhibitor $\left(\mathrm{IC}_{50}=0.03 \mu \mathrm{M}\right)$. This confirms the potency of the $\mathrm{C}^{6}$ biaryl moiety in term of $\mathrm{H}$-bonding and molecule stacking [44], since its $\mathrm{IC}_{50}$ value is close to previous results obtained on CDK5 with the 6-aminobiaryl series of inhibitors. For the drug discovery field, CDK5 is a very promising target. Indeed, this kinase is involved in multiple neuronal activities (neuronal survival and migration), development of the cerebral cortex, phosphorylation of tau and production of $\beta$-amyloïd, pain signaling and pancreatic secretion of insulin [25,51-53]. To date, CDK5 specific inhibitors reported by others include complex scaffolds such as pyrazolopyrimidines $\left(\mathrm{IC}_{50}=0.03 \mu \mathrm{M}\right)$ [54], 2,4-diaminothiazoles (IC50 values included between $0.015 \mu \mathrm{M}$ and $1 \mu \mathrm{M}$ ) [55] and cyclohexyl-thiophene moieties ( $\mathrm{IC}_{50}$ values included between $0.035 \mu \mathrm{M}$ and $1 \mu \mathrm{M}$ ) [56].

Compound 11 is a potent inhibitor of $\mathrm{CK} 1$, with an $\mathrm{IC}_{50}$ value of $0.04 \mu \mathrm{M}$. This kinase is involved in multiple physiological events, such as circadian rhythm regulation, and its implication in Alzheimer's disease was strongly suggested [43,57]. With the significant exception of our previously reported series or trisubstituted purines including DRF053 [34], known CK1 inhibitors encompass generally polycyclic complex structures, including natural products such as hymenialdisine $\left(\mathrm{IC}_{50}=0.03 \mu \mathrm{M}\right)$ [58], a pyrrole-imidazole alkaloid extracted from marine sponges, and original synthetic molecules [59]. 
Interestingly, compounds $\mathbf{5}$ and $\mathbf{6}$ retain a marked inhibitory effect on DYRK1A. This activity is very close to the $\mathrm{IC}_{50}$ (ranging from $0.21 \mu \mathrm{M}$ to $0.48 \mu \mathrm{M}$ ) that we previously reported for this kinase with other 2,6,9-trisubstituted purines [45]. Moreover this inhibition is stronger compared to that of $(R)$-roscovitine $(87 \%$ of remaining DYRK1A kinase activity at $1 \mu \mathrm{M})$ and of purvalanol A (88\% of remaining DYRK1A kinase activity at $0.1 \mu \mathrm{M}$ ) [43]. This is important because DYRK1A deregulation is involved in severe neurodegenerative pathologies, such as Down's syndrome and the cognitive deficits associated with Alzheimer's disease [60,61]. Only a few sub-micromolar DYRK1A inhibitors have been described, such as leucettines (IC50 values around $0.04 \mu \mathrm{M}$ ) [62,63], lamellarin D derivatives $\left(\mathrm{IC}_{50}=0.07 \mu \mathrm{M}\right)$ [64] or acridone alkaloids from Glycosomis chlorosperma $\left(\mathrm{IC}_{50}=0.075 \mu \mathrm{M}\right)$ [65], and synthetic original molecules, such as 4,7-disubstituted pyrido[3,2d]pyrimidines [66], 6-arylquinazolin-4-amines [67] and phtalazinone [68]. Nevertheless, these molecules have complex organic structures requiring multi-steps synthesis and their "hit to lead" optimization might be difficult. Finally, our results confirm the potency of the purine scaffold as a potent initial scaffold to develop and optimize new DYRK1A inhibitors.

\subsection{Evaluation on P. falciparum}

A selection of 15 molecules $\mathbf{4 b}-\mathbf{c}, \mathbf{1 0}-\mathbf{1 3}$ representing the different 2,6,9-trisubstituted purine series, including newly synthesized products was screened as anti-malarial agents on two different P. falciparum strains, Pf3D7, a standard drug-sensitive African stain, and Pf7G8, a brazilian chloroquino-resistant strain (Figure 3). The compound activity was evaluated during the parasitic erythocytic cycle, by the means of a $\left[{ }^{3} \mathrm{H}\right]$ hypoxanthine incorporation assay [69]. It is directly correlated to parasite viability, as described in the experimental section. $\mathrm{IC}_{50}$ values on mammalian kinases for the P. falciparum screened compounds are summarized in supplementary material, Table A1, appendix section.

At first, the activity of the fifteen compounds was screened at three different concentrations (10, 50 and $100 \mu \mathrm{M}$ ) on $\mathrm{Pf} 3 \mathrm{D} 7$. Chloroquine which is not a kinase inhibitor, but which is the antimalarial reference drug was used as the positive control. This allowed the selection of the six most active compounds, which totally inhibit the parasite proliferation during its erythrocytic cycle at a concentration of $100 \mu \mathrm{M}$. Then, in a second assay, these six molecules plus $(R)$-roscovitine (1) and purvalanol A (2a) were evaluated in a dose-dependent assay, in order to determine their IC 50 values on the two $P$. falciparum strains. Chloroquine was again used as a positive control.

As expected, each $P$. falciparum strain growth is partly inhibited by $(R)$-roscovitine and purvalanol $\mathrm{A}$, and the latter exhibited the strongest activities. Nevertheless, previous studies reported that $\mathrm{IC}_{50}$ values for purvalanol A on recombinant PfPK5 and Pfmrk are respectively of $8 \mu \mathrm{M}$ and $26 \mu \mathrm{M}$, suggesting the likely existence of alternative in vivo molecular targets [32,70].

With the marked exception of compound 20, the screened molecules in the second round of assays exhibited significant $\mathrm{IC}_{50}$ values ranging from $0.7 \mu \mathrm{M}$ to $7 \mu \mathrm{M}$ on both strains (Table 2 ) and therefore appeared to be more potent than $(R)$-roscovitine and purvalanol A [71], and also more potent than other adenine and adenosine derivatives with a purine ring [72]. 
Figure 3. Structures of the 2,6,9-trisubstituted purines screened as P. falciparum growth inhibitors ${ }^{\text {a }}$.

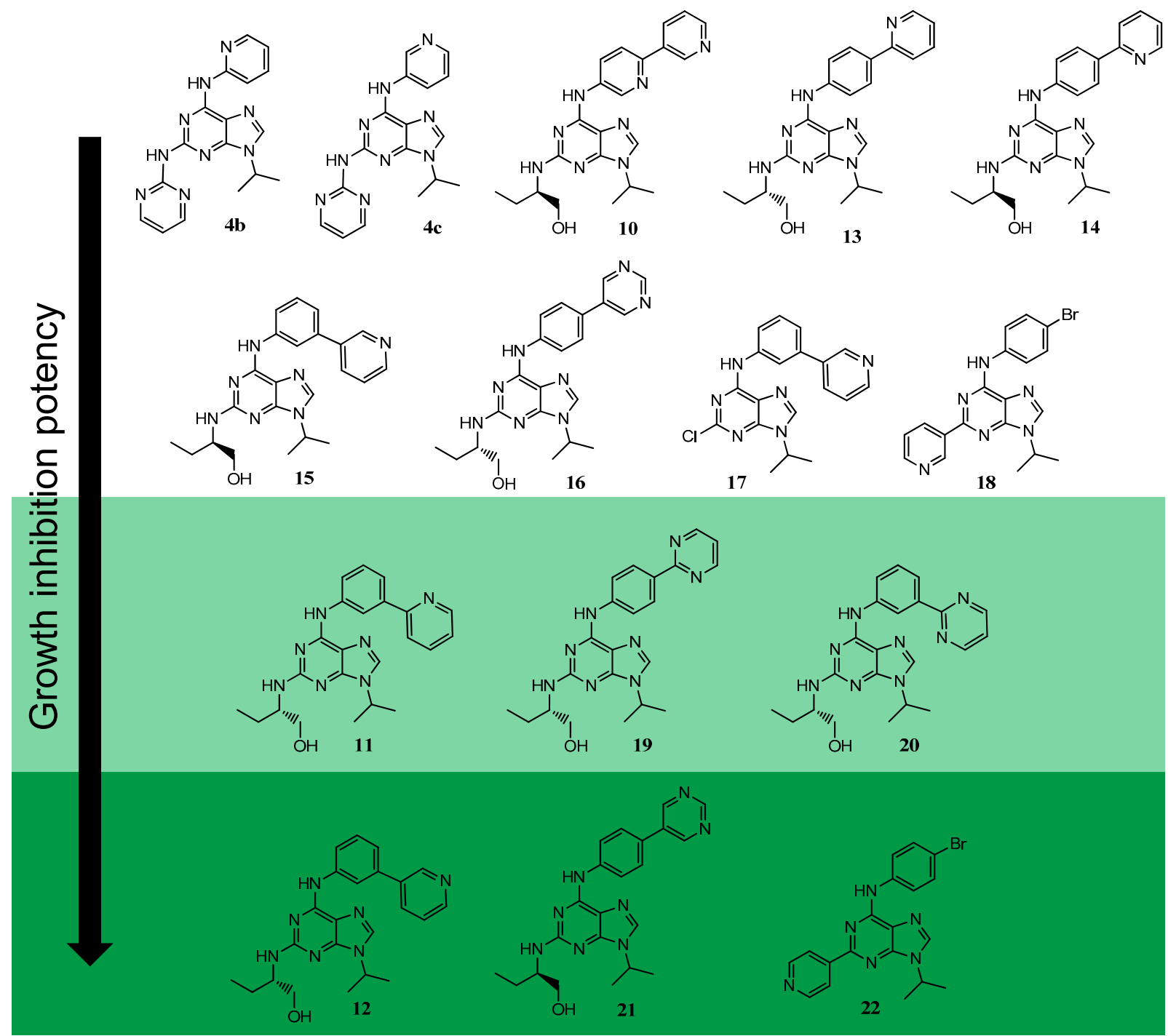

${ }^{a}$ Inactive compounds are drawn on a white background; these molecules were not selected for further $\mathrm{IC}_{50}$ measurement. Compounds with $\mathrm{IC}_{50}>6 \mu \mathrm{M}$ on Pf3D7 are drawn with light grey background. The most potent $P$. falciparum growth inhibitors are drawn with dark grey background.

Table 2. IC 50 values for $P f 3 \mathrm{D} 7$ and $P f 7 \mathrm{G} 8$ for the six mammalian kinase inhibitors and the three control molecules. These values were estimated by non-linear regression analysis using an inhibitory sigmoid $E_{\max }$ model. All assays were run in triplicates.

\begin{tabular}{ccc}
\hline \multirow{2}{*}{ Compounds } & \multicolumn{2}{c}{ Growth $\mathbf{I C}_{\mathbf{5 0}}(\boldsymbol{\mu M})$} \\
\cline { 2 - 3 } & $\boldsymbol{P f 3 D 7}$ & $\boldsymbol{P f 7 G 8}$ \\
\hline $\mathbf{1 1}$ & 6.53 & 2.06 \\
$\mathbf{1 2}$ & 5.37 & 1.55 \\
$\mathbf{1 9}$ & 7.13 & 1.82 \\
$\mathbf{2 0}$ & 22.21 & 4.66 \\
$\mathbf{2 1}$ & 3.05 & 0.69 \\
$\mathbf{2 2}$ & 1.39 & 0.99 \\
$(R)$-roscovitine, $\mathbf{1}$ & 10.48 & 12.56 \\
Purvalanol A, 2a & 4.58 & 8.12 \\
Chloroquine & 0.03 & 0.18 \\
\hline
\end{tabular}


Interestingly, these six inhibitors appeared to be 3- to 5-fold more potent against Pf7G8 than against Pf3D7 (e.g., compound 21: Pf3D7 $\mathrm{IC}_{50}=3.05 \mu \mathrm{M} v$ s. Pf7G8 IC $50=0.69 \mu \mathrm{M}$ ). Such marked sensitivity of the chloroquino-resistant strain has been frequently observed, and is generally due to an acute internalization of the drug into the protozoan. Indeed, protozoans such as P. falciparum are unable to synthesize purines de novo, and all their purines are provided by the host. To this end, these organisms have developed very effective and specific systems to take up and internalize purines. Thus, these uptake pathways might differ from one strain to another, and therefore might be the reason of these slight differences observed for P. falciparum growth inhibition. However, these differences observed between $P$. falciparum growth inhibition according to the chloroquine sensitivity could also depend on the specific PfCDK inhibited by the tested compounds which remain to be studied.

Compounds 11, 12, 21 and 22 which exhibited sub-micromolar $\mathrm{IC}_{50}$ for the mammalian kinases appeared to be promising inhibitors of $P$. falciparum growth with $\mathrm{IC}_{50}$ values around $1-5 \mu \mathrm{M}$ for both strains. These results are probably correlated with the similar sequence and structure between mammalian and protozoan kinases. Nevertheless, further "hit to lead" improvement will be necessary to improve selectivity towards protozoan growth inhibition. To address this optimization, it might be interesting to consider molecules 18 and 22 IC $_{50}$ values. Indeed, for these compounds, the protozoan growth inhibition potency is directly linked to the purine $\mathrm{C}^{2}$ pyridine core nitrogen position, suggesting a potential H-bond involving this nitrogen atom and the protozoan cellular target. This is a major difference with $\mathrm{CDK}$ inhibition, as we previously reported very close $\mathrm{IC}_{50}$ values for both of them on CDK1, CDK2 and CK1 (compound 18: CDK1 : $\mathrm{IC}_{50}=0.41 \mu \mathrm{M}$; CDK5: $\mathrm{IC}_{50}=0.73 \mu \mathrm{M}$; CK1: $\mathrm{IC}_{50}=0.10 \mu \mathrm{M}$; compound $22:$ CDK1: $\mathrm{IC}_{50}=0.59 \mu \mathrm{M} ; \mathrm{CDK} 5: \mathrm{IC}_{50}=0.60 \mu \mathrm{M} ; \mathrm{CK} 1$ : $\left.\mathrm{IC}_{50}=0.08 \mu \mathrm{M}[44]\right)$. Starting from this, a specific anti-malaria pharmacophore introduction in another position of the purine scaffold might pave the way to the design of a more specific and potent "hit".

\section{Experimental Section}

\subsection{Chemistry}

\section{General Procedures}

Chemical reagents and solvents were purchased from Sigma-Aldrich (Lyon, France), Fluka (Lyon, France) and Carlo Erba (Val de Reuil, France). Reactions were monitored by TLC using Merck (Fontenay sous Bois, France) silica gel 60F-254 thin layer plates. Column chromatographies were performed on SDS Chromagel 60 ACC 40-63 $\mu \mathrm{M}$. Melting points were determined on a Reichert Köfler hot-stage (Depew, NY, USA) and are uncorrected. NMR spectra were recorded on Bruker (Wissembourg, France) Avance $400 \mathrm{MHz}\left(100 \mathrm{MHz}\right.$ for $\left.{ }^{13} \mathrm{C}-\mathrm{NMR}\right)$ at $300 \mathrm{~K}$. Chemical shifts were reported as $\delta$ values (ppm) indirectly referenced to the solvent signal or to tetramethylsilane (TMS) as internal standards. Data are reported in the conventional form. Mass spectra were recorded on a ZQ 2000 Waters using a Z-spray (ESI-MS).

General Procedure for $N^{9}$ alkylation. To a solution of 2,6-dichloro-9H-purine or 2-amino-6-chloro$9 \mathrm{H}$-purine (1.0 eq.) in DMSO (5.5 mL for $1 \mathrm{mmol}$ of purine) at $15^{\circ} \mathrm{C}$ were added $\mathrm{K}_{2} \mathrm{CO}_{3}$ (3.0 eq.) and 2-bromopropane (5.0 eq.). After $2-3$ days stirring at $15-18{ }^{\circ} \mathrm{C}$, water was added and the solution was 
extracted with EtOAc. The organic layer, once combined, was washed with brine, dried $\left(\mathrm{Na}_{2} \mathrm{SO}_{4}\right)$, concentrated and purified by chromatography on silica gel columns (eluant: cyclohexane/EtOAc 1:9) to yield white solids $(60 \%-75 \%)$.

2-Amino-6-chloro-9-iso-propylpurine (7) and 2,6-dichloro-9-iso-propylpurine (9) have been previously synthesized [44,72]; ${ }^{1} \mathrm{H}-\mathrm{NMR},{ }^{13} \mathrm{C}-\mathrm{NRM}$ and mass spectra are in accordance with previously reported data.

General Procedure for Buchwald-Hartwig Amination. A solution of $\mathrm{Pd}(\mathrm{OAc})_{2}$ and $\mathrm{BINAP}$ in dry toluene was warmed at $45^{\circ} \mathrm{C}$ for $5 \mathrm{~min}$. The leaving group-containing purine was then added under $\mathrm{N}_{2}$ bubbling; the mixture was kept at $45{ }^{\circ} \mathrm{C}$ for $10 \mathrm{~min}$. and $\mathrm{KOtBu}$ was added. After $10 \mathrm{~min}$, the appropriate nucleophile was added. The mixture was heated at $100{ }^{\circ} \mathrm{C}$ under $\mathrm{N}_{2}$ until reaction completion ( $3 \mathrm{~h}$ to 2 days depending upon the nucleophile used). After cooling to room temperature, the mixture was filtered through Celite, and concentrated. The residue was dissolved in $\mathrm{CH}_{2} \mathrm{Cl}_{2}(75 \mathrm{~mL})$ and washed $(1 \times 10 \mathrm{~mL})$ with water and brine $(2 \times 10 \mathrm{~mL})$. The organic layer was dried and concentrated under vacuum. The residue was purified by chromatography on silica gel using various amounts of EtOAc/cyclohexane/ethanol as eluants.

We already reported chemical characterization for compounds 5, 6 and $\mathbf{6}$ '; ${ }^{1} \mathrm{H}-\mathrm{NMR},{ }^{13} \mathrm{C}-\mathrm{NMR}$ and mass spectra are in accordance with previously reported data [44].

2-Amino(pyrimidin-2-yl)-6-chloro-9-iso-propylpurine (8). ${ }^{1} \mathrm{H}-\mathrm{NMR}\left(400 \mathrm{MHz}, \mathrm{CDCl}_{3}\right.$ ): $\delta$ (ppm) 1.63 $\left(\mathrm{d}, 6 \mathrm{H}, J=6.8 \mathrm{~Hz},\left(\mathrm{CH}_{3}\right)_{2}-\mathrm{CH}\right), 4.87$ (hept, $\left.1 \mathrm{H}, J=6.8 \mathrm{~Hz}, \mathrm{CH}\left(\mathrm{CH}_{3}\right)_{2}\right), 6.95$ (t, $1 \mathrm{H}, J=4.8 \mathrm{~Hz}$, $\mathrm{H}_{\text {pyrimidinyl }}$ ), 8.00 (s, $\left.1 \mathrm{H}, \mathrm{H}-8_{\text {purine }}\right), 8.31$ (s, $\left.1 \mathrm{H}, \mathrm{NH}\right), 8.62$ (d, 2H, J=4.8 Hz, $\left.\mathrm{H}_{\text {pyrimidinyl }}\right)$.

2-Amino(pyrimidin-2-yl)-6-[4-bromophenyl]-9-iso-propylpurine (4a). ${ }^{1} \mathrm{H}-\mathrm{NMR}\left(400 \mathrm{MHz}, \mathrm{CDCl}_{3}\right): \delta$ (ppm) $1.62\left(\mathrm{~d}, 6 \mathrm{H}, J=6.8 \mathrm{~Hz},\left(\mathrm{CH}_{3}\right)_{2}-\mathrm{CH}\right), 4.81$ (hept, $\left.1 \mathrm{H}, J=6.8 \mathrm{~Hz}, \mathrm{CH}\left(\mathrm{CH}_{3}\right)_{2}\right), 6.95(\mathrm{t}, 1 \mathrm{H}, J=4.8 \mathrm{~Hz}$,

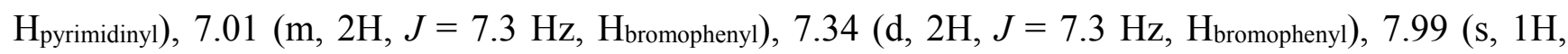

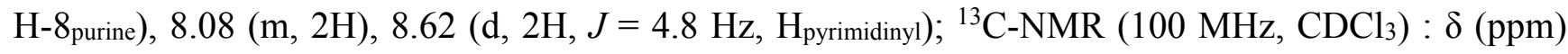
$21.4,45.3,114.9,116.7,120.4,121.2$, 133.4, 137.6, 147.9, 150.9, 151.3, 157.2, 157.3, 159.5; MS $\left(\mathrm{ES}^{+}\right) \mathrm{m} / z 425.08[\mathrm{M}+\mathrm{H}]^{+}$.

2-Amino(pyrimidin-2-yl)-6-[pyridin-2-yl]-9-iso-propylpurine (4b). ${ }^{1} \mathrm{H}-\mathrm{NMR}\left(400 \mathrm{MHz}, \mathrm{CDCl}_{3}\right): \delta$ (ppm) $1.62\left(\mathrm{~d}, 6 \mathrm{H}, J=6.8 \mathrm{~Hz},\left(\mathrm{CH}_{3}\right)_{2}-\mathrm{CH}\right), 4.80$ (hept, $\left.1 \mathrm{H}, J=4.8 \mathrm{~Hz}, \mathrm{CH}\left(\mathrm{CH}_{3}\right)_{2}\right), 6.92$ (t, $1 \mathrm{H}, J=4.8 \mathrm{~Hz}$, $\mathrm{H}_{\text {pyrimidinyl }),} 6.99$ (m, 1H, $\left.\mathrm{H}_{\text {pyridyl }}\right), 7.54$ (m, 1H, $\left.\mathrm{H}_{\text {pyridyl }}\right), 7.83$ (s, 1H, H-8 purine $_{\text {) }}, 8.12$ (bs, 2H, NH), 8.32 (m, $\left.1 \mathrm{H}, \mathrm{H}_{\text {pyridyl }}\right), 8.62$ (d, 2H, $J=4.8 \mathrm{~Hz}, \mathrm{H}_{\text {pyrimidinyl }),} 9.29$ (m, 1H, $\left.\mathrm{H}_{\text {pyridyl }}\right) ;{ }^{13} \mathrm{C} \mathrm{NMR}(100 \mathrm{MHz}$, $\left.\mathrm{CDCl}_{3}\right): \delta$ (ppm) 22.4, 22.5, 45.3, 113.7, 114.9, 117.8, 120.4, 133.4, 137.6, 147.9, 149.4, 150.7, 151.2, 157.4, 158.0, 159.4; $\mathrm{MS}\left(\mathrm{ES}^{+}\right) \mathrm{m} / z 348.08[\mathrm{M}+\mathrm{H}]^{+}$.

2-Amino(pyrimidin-2-yl)-6-[pyridin-3-yl]-9-iso-propylpurine (4c). ${ }^{1} \mathrm{H}-\mathrm{NMR}\left(400 \mathrm{MHz}, \mathrm{CDCl}_{3}\right): \delta$ (ppm) $1.62\left(\mathrm{~d}, 6 \mathrm{H}, J=6.8 \mathrm{~Hz},\left(\mathrm{CH}_{3}\right)_{2}-\mathrm{CH}\right), 4.81$ (hept, $\left.1 \mathrm{H}, J=6.8 \mathrm{~Hz}, \mathrm{CH}\left(\mathrm{CH}_{3}\right)_{2}\right), 6.93(\mathrm{t}, 1 \mathrm{H}, J=4.8 \mathrm{~Hz}$,

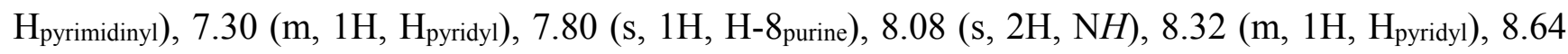
(d, $\left.2 \mathrm{H}, J=4.8 \mathrm{~Hz}, \mathrm{H}_{\text {pyrimidinyl }}\right), 8.86\left(\mathrm{~m}, 1 \mathrm{H}, \mathrm{H}_{\text {pyridyl }}\right), 9.14$ (s, 1H, $\left.\mathrm{H}_{\text {pyridyl }}\right) .{ }^{13} \mathrm{C}-\mathrm{NMR}(100 \mathrm{MHz}$, $\left.\mathrm{CDCl}_{3}\right): \delta$ (ppm) 22.4, 45.3, 113.7, 114.6, 123.2, 126.7, 135.4, 136.4, 141.9, 142.9, 150.7, 151.2, 157.6, 158.1, 159.0; $\mathrm{MS}\left(\mathrm{ES}^{+}\right) \mathrm{m} / z$ 348.14 [M+H] $]^{+}$. 
2-Amino(pyrimidin-2-yl)-6-[pyridin-4-yl]-9-iso-propylpurine (4d). ${ }^{1} \mathrm{H}-\mathrm{NMR}\left(400 \mathrm{MHz}, \mathrm{CDCl}_{3}\right): \delta$ (ppm) $1.61\left(\mathrm{~d}, 6 \mathrm{H}, J=6.8 \mathrm{~Hz},\left(\mathrm{CH}_{3}\right)_{2}-\mathrm{CH}\right), 4.82$ (hept, $\left.1 \mathrm{H}, J=6.8 \mathrm{~Hz}, \mathrm{CH}\left(\mathrm{CH}_{3}\right)_{2}\right), 6.93(\mathrm{t}, 1 \mathrm{H}, J=4.8 \mathrm{~Hz}$, $\mathrm{H}_{\text {pyrimidinyl) }} 7.76$ (s, 1H, H-8purine), 7.69 (d, 2H, J = 6.0 Hz, Hpyridyl), 8.00 (s, 2H, NH), 8.32 (d, 1H, $J=4.8 \mathrm{~Hz}), 8.64\left(\mathrm{~d}, 2 \mathrm{H}, J=4.8 \mathrm{~Hz}, \mathrm{H}_{\text {pyrimidinyl }}\right), 8.41$ (d, 2H, $\left.J=6.0 \mathrm{~Hz}, \mathrm{H}_{\text {pyridyl }}\right) .{ }^{13} \mathrm{C} \mathrm{NMR}(100 \mathrm{MHz}$, $\left.\mathrm{CDCl}_{3}\right): \delta$ (ppm) 22.3, 46.1, 113.4, 115.5, 135.4, 136.4, 141.9, 142.9, 150.7, 151.2, 157.7, 158.1, 159.0.

Chemical Characterizations of Compounds 10-13. These compounds have been obtained following a previously reported synthesis strategy. See references [43] and [46] for the details of corresponding experimental procedures and characterizations of intermediates.

(R)-2-(1-Hydroxybut-2-ylamino)-6-[6-(3-pyridyl)pyrid-3-ylamino]-9-iso-propylpurine (10). ${ }^{1} \mathrm{H}-\mathrm{NMR}$ (400 MHz, $\left.\mathrm{CDCl}_{3}\right): \delta(\mathrm{ppm}) 1.00\left(\mathrm{t}, 3 \mathrm{H}, J=7.0 \mathrm{~Hz}, \mathrm{CH}_{3} \mathrm{CH}_{2}\right), 1,50\left(\mathrm{~d}, 6 \mathrm{H}, J=6.9 \mathrm{~Hz}, \mathrm{CH}\left(\mathrm{CH}_{3}\right)_{2}\right)$, 1.45-1.7 (m, 2H, $\left.\mathrm{CH}_{2} \mathrm{CH}_{3}\right), 3.5\left(\mathrm{~m}, 1 \mathrm{H}, \mathrm{CH}_{2} \mathrm{OH}\right), 3.8\left(\mathrm{~d}, 1 \mathrm{H}, J=3.1 \mathrm{~Hz}\right.$ and $\left.J=10.2 \mathrm{~Hz}, \mathrm{CH}_{2} \mathrm{OH}\right), 3.9$ $(\mathrm{m}, 1 \mathrm{H}, \mathrm{CHNH}), 4.53$ (hept, $\left.1 \mathrm{H}, J=6.9 \mathrm{~Hz}, \mathrm{CH}\left(\mathrm{CH}_{3}\right)_{2}\right), 7.3\left(\mathrm{~d}, 1 \mathrm{H}, J=8.0 \mathrm{~Hz}, \mathrm{H}_{\text {pyridyl }}\right), 7.55$ (s, $1 \mathrm{H}$, H-8 $\left.8_{\text {purine }}\right), 7.7$ (d, 1H, $\left.J=8.0 \mathrm{~Hz}, \mathrm{H}_{\text {pyridyl }}\right), 7.75$ (m, 2H, NH), 8.2-8.3 (m, 2H, $\left.\mathrm{H}_{\text {pyridyl) }}\right), 8.55$ (s, 1H, $\left.\mathrm{H}_{\text {pyridyl }}\right), 9\left(\mathrm{~d}, 1 \mathrm{H}, J=8.0 \mathrm{~Hz}, \mathrm{H}_{\text {pyridyl }}\right), 9,1$ (s, $\left.1 \mathrm{H}, \mathrm{H}_{\text {pyridyl }}\right) .{ }^{13} \mathrm{C}-\mathrm{NMR}\left(100 \mathrm{MHz}, \mathrm{CDCl}_{3}\right): \delta$ (ppm) $10.8,22.0,23.1,47.8,55.9,67.0,120.8,124.4,134.5,139.7,140.3,141.5,147.9,149.9,150.8,151.9$, $157.4,159.8$

(S)-2-(1-Hydroxybut-2-ylamino)-6-[3-(2-pyridyl)phenylamino]-9-iso-propylpurine (11). $\quad{ }^{1} \mathrm{H}-\mathrm{NMR}$ (400 MHz, $\left.\mathrm{CDCl}_{3}\right): \delta(\mathrm{ppm}) 0.98\left(\mathrm{t}, 3 \mathrm{H}, J=7.2 \mathrm{~Hz}, \mathrm{CH}_{3} \mathrm{CH}_{2}\right), 1.49\left(\mathrm{~d}, 6 \mathrm{H}, J=6.8 \mathrm{~Hz}, \mathrm{CH}\left(\mathrm{CH}_{3}\right)_{2}\right)$, $1.67-1.78\left(\mathrm{~m}, 2 \mathrm{H}, \mathrm{CH}_{3} \mathrm{CH}_{2}\right), 3.63\left(\mathrm{~m}, 1 \mathrm{H}, \mathrm{CH}_{2} \mathrm{OH}\right), 3.74(\mathrm{dd}, 1 \mathrm{H}, J=2.4 \mathrm{~Hz}$ and $J=10.6 \mathrm{~Hz}$, $\left.\mathrm{CH}_{2} \mathrm{OH}\right), 3.97-4.05(\mathrm{~m}, 1 \mathrm{H}, \mathrm{CHNH}), 4.58$ (hept, $\left.1 \mathrm{H}, J=6.8 \mathrm{~Hz}, \mathrm{CH}\left(\mathrm{CH}_{3}\right)_{2}\right), 4.94(\mathrm{~m}, 1 \mathrm{H}, \mathrm{CHNH})$, $7.10-7.15$ (m, 2H, $\left.\mathrm{H}_{\text {pyridyl }}\right), 7.38$ (t, $\left.1 \mathrm{H}, J=7.2 \mathrm{~Hz}, \mathrm{H}_{\text {phenyl }}\right), 7.50-7.54$ (m, 2H, $\mathrm{H}_{\text {phenyl }}+\mathrm{H}_{\text {pyridyl }}$ ), 7.68-7.71 (m, 3H, $\left.\mathrm{H}_{\text {phenyl }}+\mathrm{H}_{\text {pyridyl }}\right), 7.86$ (s, $1 \mathrm{H}, \mathrm{H}-8$ purine $), 8.62\left(\mathrm{~d}, 1 \mathrm{H}, J=4.3 \mathrm{~Hz}, \mathrm{H}_{\text {pyridyl }}\right) .{ }^{13} \mathrm{C}-\mathrm{NMR}$ $\left(100 \mathrm{MHz} \mathrm{CDCl}_{3}\right): \delta(\mathrm{ppm}) 10.8,22.5,22.6,24.9,46.4,55.9,66.7,114.9,118.6,120.3,121.0,121.4$, $122.2,129.1,135.1,136.9,139.8,140.1,149.4,152.2,157.3,159.6$.

(S)-2-(1-Hydroxybut-2-ylamino)-6-[3-(3-pyridyl)phenylamino]-9-iso-propylipurine (12). ${ }^{1} \mathrm{H}-\mathrm{NMR}$ (400 MHz, $\left.\mathrm{CDCl}_{3}\right): \delta(\mathrm{ppm}) 0.94\left(\mathrm{t}, 3 \mathrm{H}, J=6.8 \mathrm{~Hz}, \mathrm{CH}_{3} \mathrm{CH}_{2}\right), 1.49$ (d, $\left.6 \mathrm{H}, J=6.8 \mathrm{~Hz}, \mathrm{CH}\left(\mathrm{CH}_{3}\right)_{2}\right)$, 1.53-1.66 (m, 2H, $\left.\mathrm{CH}_{3} \mathrm{CH}_{2}\right), 3.61\left(\mathrm{~m}, 1 \mathrm{H}, \mathrm{CH} \mathrm{H}_{2} \mathrm{OH}\right), 3.78\left(\mathrm{~m}, 1 \mathrm{H}, \mathrm{CH}_{2} \mathrm{OH}\right), 3.88-3.98(\mathrm{~m}, 1 \mathrm{H}$, $\mathrm{C} H \mathrm{NH}), 4.56$ (hept, $\left.1 \mathrm{H}, J=6.8 \mathrm{~Hz}, \mathrm{CH}\left(\mathrm{CH}_{3}\right)_{2}\right), 4.94(\mathrm{~d}, 1 \mathrm{H}, J=6.1 \mathrm{~Hz}, \mathrm{CHNH}), 7.10-7.15$ (m, 2H, $\mathrm{H}_{\text {pyridyl }}$ ), 7.29 (m, 1H, $\left.\mathrm{H}_{\text {pyridyl) }}\right), 7.37$ (t, $\left.1 \mathrm{H}, J=7.2 \mathrm{~Hz}, \mathrm{H}_{\text {pyridyl }}\right), 7.53$ (s, 1H, H-8 purine), $7.62-7.70$ (m, $\left.2 \mathrm{H}, \mathrm{H}_{\text {phenyl }}+\mathrm{H}_{\text {pyridyl }}\right), 7.82\left(\mathrm{~d}, 1 \mathrm{H}, J=7.6 \mathrm{~Hz}, \mathrm{H}_{\text {phenyl }}\right), 7.99$ (s, 1H, $\left.\mathrm{H}_{\text {phenyl }}\right), 8.52$ (d, 1H, J = 4.1 Hz, $\mathrm{H}_{\text {pyridyl }}$ ), 8.81 (s, $\left.1 \mathrm{H}, \mathrm{H}_{\text {pyridyl }}\right) .{ }^{13} \mathrm{C} \mathrm{NMR}\left(100 \mathrm{MHz}, \mathrm{CDCl}_{3}\right): \delta$ (ppm) 10.8, 22.5, 24.7, 46.6, 56.0, 67.2, $115.1,118.5,119.5,121.6,123.5,129.5,134.5,135.3,136.5,138.5,139.8,148.3,148.5,152.3,159.6$.

(S)-2-(1-Hydroxybut-2-ylamino)-6-[4-(2-pyridyl)phenylamino]-9-iso-propylpurine (13). $\quad{ }^{1} \mathrm{H}-\mathrm{NMR}$ $\left(400 \mathrm{MHz}, \mathrm{CDCl}_{3}\right): \delta(\mathrm{ppm}) 0.98\left(\mathrm{t}, 3 \mathrm{H}, J=7.2 \mathrm{~Hz}, \mathrm{CH}_{3} \mathrm{CH}_{2}\right), 1.46\left(\mathrm{~d}, 6 \mathrm{H}, J=6.8 \mathrm{~Hz}, \mathrm{CH}\left(\mathrm{CH}_{3}\right)_{2}\right)$, $1.52-1.68\left(\mathrm{~m}, 2 \mathrm{H}, \mathrm{CH}_{3} \mathrm{CH}_{2}\right), 3.63\left(\mathrm{dd}, 1 \mathrm{H}, J=6.7 \mathrm{~Hz}\right.$ and $\left.J^{`}=10.8 \mathrm{~Hz}, \mathrm{CH}_{2} \mathrm{OH}\right), 3.81(\mathrm{dd}, 1 \mathrm{H}, J=2.8 \mathrm{~Hz}$ and $\left.J=10.8 \mathrm{~Hz}, \mathrm{CH}_{2} \mathrm{OH}\right), 3.90-3.95(\mathrm{~m}, 1 \mathrm{H}, \mathrm{CHNH}), 4.53$ (hept., $\left.1 \mathrm{H}, J=6.8 \mathrm{~Hz}, \mathrm{CH}\left(\mathrm{CH}_{3}\right)_{2}\right), 5.05$

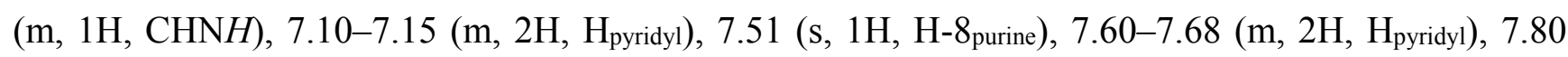
(d, $\left.2 \mathrm{H}, J=8.4 \mathrm{~Hz}, \mathrm{H}_{\text {phenyl }}\right), 7.90$ (d, $\left.2 \mathrm{H}, J=8.4 \mathrm{~Hz}, \mathrm{H}_{\text {phenyl }}\right), 8.59$ (m, $\left.1 \mathrm{H}, \mathrm{H}_{\text {pyridyl }}\right) .{ }^{13} \mathrm{C}-\mathrm{NMR}$ 
$\left(100 \mathrm{MHz}, \mathrm{CDCl}_{3}\right): \delta(\mathrm{ppm}) 10.4,21.8,24.5,45.8,55.4,65.8,114.3,119.5,119.6,121.1,127.0$, $132.7,134.7,136.4,140.1,148.7,150.5,151.4,158.8,159.7$.

\subsection{Biology-Protein Kinase Assays}

\subsubsection{Biochemical Reagents}

Sodium orthovanadate, EGTA, EDTA, MOPS, $\beta$-glycerophosphate, phenylphosphate, sodium fluoride, dithiothreitol (DTT), glutathione-agarose, glutathione, bovine serum albumin (BSA), nitrophenylphosphate, leupeptine, aprotinine, pepstatin, soybean trypsin inhibitor, benzamidine, and histone H1 (type III-S) were obtained from Sigma Chemicals (Lyon, France). $\left[\gamma_{-}{ }^{33} \mathrm{P}\right]$-ATP was obtained from Amersham (Pittsburgh, PA, USA). The CK-S peptide (RRKHAAIGpSAYSITA) (pS stands for phosphorylated serine) was purchased from Millegen (Labege, France), and the GS-1 peptide (YRRAAVPPSPSLSRHSSPHQpSEDEEE) was obtained from GenScript Corporation (Piscataway, NJ, USA).

\subsubsection{Buffers}

Buffer A: $10 \mathrm{mM} \mathrm{MgCl}$, $1 \mathrm{mM}$ EGTA, $1 \mathrm{mM}$ DTT, $25 \mathrm{mM}$ Tris-HCl pH 7.5, $50 \mu \mathrm{g}$ heparin/mL. Buffer C: $60 \mathrm{mM} \beta$-glycerophosphate, $15 \mathrm{mM}$ p-nitrophenylphosphate, $25 \mathrm{mM}$ MOPS (pH 7.2), $5 \mathrm{mM}$ EGTA, $15 \mathrm{mM} \mathrm{MgCl}_{2}, 1 \mathrm{mM}$ DTT, $1 \mathrm{mM}$ sodium vanadate, $1 \mathrm{mM}$ phenylphosphate.

\subsubsection{Kinase Preparations and Assays}

Kinase activities were assayed in Buffer A or $\mathrm{C}$, at $30{ }^{\circ} \mathrm{C}$, at a final ATP concentration of $15 \mu \mathrm{M}$. Blank values were subtracted and activities expressed in \% of the maximal activity, i.e., in the absence of inhibitors. Controls were performed with appropriate dilutions of DMSO.

CDK1/cyclin B (M phase starfish oocytes, native), CDK2/cyclin A (human, recombinant) and CDK5/p25 (human, recombinant) were prepared as previously described [73]. Their kinase activity was assayed in buffer $\mathrm{C}$, with $1 \mathrm{mg}$ histone $\mathrm{H} 1 / \mathrm{mL}$, in the presence of $15 \mu \mathrm{M}\left[\gamma^{3}{ }^{33} \mathrm{P}\right]$ ATP $(3000 \mathrm{Ci} / \mathrm{mmol}$; $10 \mathrm{mCi} / \mathrm{mL}$ ) in a final volume of $30 \mu \mathrm{L}$. After $30 \mathrm{~min}$ incubation at $30{ }^{\circ} \mathrm{C}, 25 \mu \mathrm{L}$ aliquots of supernatant were spotted onto $2.5 \mathrm{~cm} \times 3 \mathrm{~cm}$ pieces of Whatman P81 phosphocellulose paper, and, $20 \mathrm{~s}$ later, the filters were washed five times (for at least $5 \mathrm{~min}$ each time) in a solution of $10 \mathrm{~mL}$ of phosphoric acid/liter of water. The wet filters were counted in the presence of $1 \mathrm{~mL}$ of ACS (Amersham, Pittsburgh, PA, USA) scintillation fluid.

GSK-3 $\alpha / \beta$ (porcine brain, native) was assayed, as described for CDK1 but in Buffer A and using a GSK-3 specific substrate (GS-1: YRRAAVPPSPSLSRHSSPHQSpEDEEE) (pS stands for phosphorylated serine).

$\mathrm{CK} 1 \delta / \varepsilon$ (porcine brain, native) was assayed in three-fold diluted buffer C, as described for CDK1 but using $25 \mu \mathrm{M}$ CKS peptide (RRKHAAIGpSAYSITA), a CK1-specific substrate [74].

DYRK1A (human, recombinant, expressed in E. coli as a GST fusion protein) was purified by affinity chromatography on glutathione-agarose and assayed in buffer A $(+0.5 \mathrm{mg} \mathrm{BSA} / \mathrm{mL})$ with using Woodtide (KKISGRLSPIMTEQ) (1.5 $\mu \mathrm{g} /$ assay) as a substrate. 


\subsection{Biology-In Vitro Drug Susceptibility Assays}

Compounds were tested against synchronous ring-stage parasites of $P f 3 \mathrm{D} 7$ and $P f 7 \mathrm{G} 8$ strains. Drugs testing were carried out in 96-well microtiter plates. The chloroquine (CQ) diphosphate was purchased from Sigma (Lyon, France). The CQ was dissolved and diluted in water to obtain final concentrations ranging from 12.5 to $3,200 \mathrm{nM}$. The compounds were dissolved in DMSO and diluted in RPMI 1640 to obtain final concentrations ranging $0.1 \mu \mathrm{M}$ to $100 \mu \mathrm{M}$. For each assay, each drug dilution was analyzed in triplicate.

For the in vitro isotopic microtest, $200 \mu \mathrm{L}$ of the suspension of synchronous parasitized red blood cells with $>90 \%$ of the parasites at the ring stage (final parasitaemia, $0.3 \%$; final haematocrit, $4 \%$ ) per well were plated in 96-well plates that contained serial CQ or compounds concentrations. Parasite growth was measured by the incorporation of radiolabeled $\left[{ }^{3} \mathrm{H}\right]$ hypoxanthine with a specific activity of $14.1 \mathrm{Ci} / \mathrm{mmol}$ (Perkin-Elmer, Courtaboeuf, France) $(1 \mu \mathrm{Ci}$ per well) to each well at time zero. The plates were incubated at $37{ }^{\circ} \mathrm{C}$, in an atmosphere of $5 \% \mathrm{O}_{2}, 5 \% \mathrm{CO}_{2}$, and $90 \% \mathrm{~N}_{2}$ for $48 \mathrm{~h}$. Immediately after incubation, plates were frozen and then thawed to lyse the erythrocytes. Cultures were harvested onto glass fiber filters and washed using a cell harvester (FilterMAT; Skatron Instruments, Dalsletta, Norway). The dried fiber filter papers were mixed with $2 \mathrm{~mL}$ of scintillation fluid (OptiScint; Perkin-Elmer, Waltham, UK). The radioactivity was counted using a liquid scintillation counter (Wallac 1410; Perkin-Elmer, Waltham, UK). The results were recorded as counts per minute (cpm) per well at each drug concentration. The drug concentration that could inhibit $50 \%$ of the parasite growth $\left(\mathrm{IC}_{50}\right)$ were estimated by non-linear regression analysis using an inhibitory sigmoid $E_{\max }$ model (percent) $=100-\left[\left(100 \times C^{\gamma}\right) /\left(C^{\gamma}+\mathrm{IC}_{50}{ }^{\gamma}\right)\right]$, where $C$ corresponds to the drug concentration and $\gamma$ is the sigmoidicity factor. The initial value and the asymptotic result for high concentrations were fixed to $0 \%$ and $100 \%$, respectively [75], available on the web [76].

\section{Conclusions}

Using a convergent synthesis route which includes as a key step a Buchwald-Hartwig amination, we report the synthesis of new series of 2,6,9-trisubstituted purines structurally-related to $(R)$-roscovitine. The evaluation of these molecules as inhibitors on a mammalian kinases panel revealed that several compounds (5, 6, 10 and 11) exhibit marked activities against CDK5, CK1 and DYRK1A, a set of kinases involved in several neuronal pathologies such as Down Syndrome and Alzheimer's disease. These molecules might be considered as starting "hits" for further structural optimization.

These newly-synthesized purines were also evaluated as potential inhibitors of $P$. falciparum growth in vitro. By means of a two-step screening assay, we identified six molecules which are more potent against the two P. falciparum clones (Pf3D7 and Pf7G8) than (R)-roscovitine and purvalanol A. By comparison with chloroquine, these growth inhibitions are still modest, but further structural optimizations of the purine scaffold are possible. Thus, further studies should allow us to determine whether potent anti-malarial motives might be introduced into the purine scaffold. Another key point to address will be the improvement of the compound selectivity, as our strongest $P$. falciparum growth inhibitors also appeared among the best mammalian CDK inhibitors we designed. 
Altogether, these results open the way to further synthesis of new drugs targeting one of the most deadly disease in the world, malaria.

\section{Acknowledgments}

This research was supported by grants from the "Cancéropole Grand-Ouest" grant (LM), the "Institut National du Cancer" (INCa «Cancer Détection d'innovations 2006») (LM), the "Association France-Alzheimer Finistère" (LM), the "Ligue Nationale contre le Cancer (Grand-Ouest)" (LM) and the Universite Paris Descartes "BQR grant" ( $\mathrm{SH}, \mathrm{HG}, \mathrm{LD})$. LM acknowledges the support of the European Union 7th Framework Program Knowledge-Based Bio- economy (FP7-KBBE)- BlueGenics 2012 grant.

\section{Author Contributions}

L.D., N.-T.H. synthesized the molecules; S.H., N.-T.H. performed P. falciparum growth inhibition experiments; O.L. performed HsCDK inhibition experiments; L.D., S.H., J.L.B., L.M., H.G. designed experiments and reviewed the manuscript; L.D. wrote the paper; L.D., S.H., L.M., H.G. co-directed the work.

\section{Appendix}

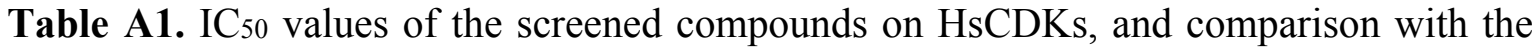
Plasmodium faciparum 3D7 and 7G8 strains growth inhibition. Purines were tested at various concentrations as described in experimental section. $\mathrm{IC}_{50}$ values are reported in $\mu \mathrm{M}$. On mammalian kinases, $\mathrm{IC}_{50}$ were estimated from dose-response curves and are expressed in $\mu \mathrm{M}$. All assays were run in triplicates and data points were within less than a $10 \%$ range. -, not tested. $\mathrm{IC}_{50}$ value reported as $>10$ means that less than $50 \%$ inhibition at $10 \mu \mathrm{M}$ was observed; N.I. (Not Inhibitor) indicates that the compound did not display any inhibitory activity. On $P f$ strains, $\mathrm{IC}_{50}$ were estimated by non-linear regression analysis using an inhibitory sigmoid $E_{\max }$ model. All assays were run in triplicates.

\begin{tabular}{cccccc}
\hline \multirow{2}{*}{ Compounds } & IC $_{\mathbf{5 0}}$ on $\boldsymbol{P .}$ falciparum & Strains $(\boldsymbol{\mu M})$ & & \multicolumn{2}{c}{ IC $_{\mathbf{5 0}}$ on HsCDKs $(\boldsymbol{\mu M})$} \\
\cline { 2 - 3 } \cline { 5 - 6 } & $\boldsymbol{P f 3 D 7}$ & $\boldsymbol{P f 7 G 8}$ & & HsCDK1 & HsCDK5 \\
\hline $\mathbf{1}$ & 10.48 & 12.56 & & 0.35 & 0.20 \\
$\mathbf{2 a}$ & 4.58 & 8.12 & & 0.004 & 0.075 \\
$\mathbf{4 b}$ & N.I. & N.I. & & 12 & $>10$ \\
$\mathbf{4 c}$ & N.I. & N.I. & & 3.0 & 4.3 \\
$\mathbf{1 0}$ & N.I. & N.I. & & 0.01 & 0.05 \\
$\mathbf{1 1}$ & 6.53 & 2.06 & & 0.8 & 0.4 \\
$\mathbf{1 2}$ & 5.37 & 1.55 & & 0.2 & 0.1 \\
$\mathbf{1 3}$ & N.I. & N.I. & & 0.2 & - \\
$\mathbf{1 4}$ & N.I. & N.I. & & 0.05 & 0.03 \\
$\mathbf{1 5}$ & N.I. & N.I. & & 0.18 & 0.05 \\
$\mathbf{1 6}$ & N.I. & N.I. & & 0.18 & 0.10 \\
$\mathbf{1 7}$ & N.I. & N.I. & 0.18 & 0.05 \\
\hline
\end{tabular}


Table A1. Cont.

\begin{tabular}{cccccc}
\hline \multirow{2}{*}{ Compounds } & \multicolumn{2}{c}{ IC $_{\mathbf{5 0} \text { on } \boldsymbol{P} \text {. falciparum }}$ Strains $(\boldsymbol{\mu M})$} & & \multicolumn{2}{c}{ IC $_{\mathbf{5 0}}$ on HsCDKs $(\boldsymbol{\mu M})$} \\
\cline { 2 - 3 } \cline { 6 - 6 } & $\boldsymbol{P f 3 D 7}$ & $\boldsymbol{P f 7 G 8}$ & & HsCDK1 & HsCDK5 \\
\hline $\mathbf{1 8}$ & N.I. & N.I. & & 0.41 & 0.73 \\
$\mathbf{1 9}$ & 7.13 & 1.82 & & 0.5 & 0.27 \\
$\mathbf{2 0}$ & 22.21 & 4.66 & & 0.7 & 0.5 \\
$\mathbf{2 1}$ & 3.05 & 0.69 & & 0.04 & 0.06 \\
$\mathbf{2 2}$ & 1.39 & 0.99 & & 0.6 & 0.6 \\
\hline
\end{tabular}

\section{Conflicts of Interest}

All the authors have read the manuscript, concur with its content, and state that its content has not been submitted elsewhere. The authors declare no competing financial interests and no conflict of interest.

\section{References}

1. World Malaria Report 2013; WHO Press: Geneva, Switzerland, 2013. Available online: http://www.who.int (accessed on 22 September 2014)

2. Robert, V.; Boudin, C. Biologie de la transmission homme-moustique du plasmodium. Bull. Soc. Pathol. Exot. 2003, 96, 6-20.

3. Park, D.J.; Lukens, A.K.; Neafsey, D.E.; Schaffner, S.F.; Chang, H.-H.; Valim, C.; Ribacke, U.; van Tyne, D.; Galinsky, K.; Galligan, M.; et al. Sequence-Based association and selection scans identify drug resistance loci in the plasmodium falciparum malaria parasite. Proc. Natl. Acad. Sci. USA 2012, 109, 13052-13057.

4. Fairhurst, R.M.; Nayyar, G.M.; Breman, J.G.; Hallett, R.; Vennerstrom, J.L.; Duong, S.; Ringwald, P; Wellems, T.E.; Plowe, C.V.; Dondorp, A.M. Artemisinin-resistant malaria: Research challenges, opportunities, and public health implications. Am. J. Trop. Med. Hyg. 2012, 87, 231-241.

5. Wittlin, S.; Ekland, E.; Craft, J.C.; Lotharius, J.; Bathurst, I.; Fidock, D.A.; Fernandes, P. In vitro and in vivo activity of solithromycin (CEM-101) against plasmodium species. Antimicrob. Agents Chemother. 2012, 56, 703-707.

6. Aureggi, V.; Ehmke, V.; Wieland, J.; Schweizer, W.B.; Bernet, B.; Bur, D.; Meyer, S.; Rottmann, M.; Freymond, C.; Brun, R.; et al. Potent inhibitors of malarial aspartic proteases, the plasmepsins, by hydroformylation of substituted 7-azanorbornenes. Chem. Eur. J. 2012, 19, 155-164.

7. Rodrigues, T.; Lopes, F.; Moreira, R. Inhibitors of the mitochondrial electron transport chain and de novo pyrimidine biosynthesis as antimalarials: the present status. Curr. Med. Chem. 2010, 17, 926-956.

8. Rotella, D.P. Recent results in protein kinase inhibition for tropical diseases. Bioorg. Med. Chem. Lett. 2012, 22, 6788-6793.

9. Doerig, C. Protein kinases as targets for anti-parasitic chemotherapy. Biochim. Biophys. Acta 2004, 1697, 155-168. 
10. Doerig, C.; Billker, O.; Pratt, D.; Endicott, J. Protein kinases as targets for antimalarial intervention: Kinomics, structure-based design, transmission-blockade, and targeting host cell enzymes. Biochim. Biophys. Acta 2005, 1754, 132-150.

11. Doerig, C.; Meijer, L. Antimalarial drug discovery: Targeting protein kinases. Expert Opin. Ther. Targets 2007, 11, 279-290.

12. Noguchi, Y.; Yasuda, Y.; Tashiro, M.; Kataoka, T.; Kitamura, Y.; Kandeel, M.; Kitade, Y. Synthesis of carbocyclic pyrimidine nucleosides and their inhibitory activities against Plasmodium falciparum thymidylate kinase. Parasitol. Int. 2013, 62, 368-371.

13. Taylor, H.M.; McRobert, L.; Grainger, M.; Sicard, A.; Dluzewski, A.R.; Hopp, C.S.; Holder, A.A.; Baker, D.A. The malaria parasite cyclic GMP-dependent protein kinase plays a central role in blood-stage schizogony. Eukaryot. Cell 2010, 9, 37-45.

14. Chapman, T.M.; Osborne, S.A.; Bouloc, N.; Large, J.M.; Wallace, C.; Birchall, K.; Ansell, K.H.; Jones, H.M.; Taylor, D.; Clough, B.; et al. Substituted imidazopyridazines are potent and selective inhibitors of Plasmodium falciparum calcium-dependent protein kinase 1 (PfCDPK1). Bioorg. Med. Chem. Lett. 2013, 23, 3064-3069.

15. Chapman, T.M.; Osborne, S.A.; Wallace, C.; Birchall, K.; Bouloc, N.; Jones, H.M.; Ansell, K.H.; Taylor, D.L.; Clough, B.; Green, J.L.; et al. Optimization of an imidazopyridazine series of inhibitors of Plasmodium falciparum calcium-dependent protein kinase 1 (PfCDPK1). J. Med. Chem. 2014, 57, 3570-3587.

16. Nag, S.; Chouhan, D.K.; Balaji, S.N.; Chakraborty, A.; Lhouvum, K.; Bal, C.; Sharon, A.; Trivedi, V. Comprehensive screening of heterocyclic compound libraries to identify novel inhibitors for PfRIO-2 kinase through docking and substrate competition studies. Med. Chem. Res. 2013, 22, 4737-4744.

17. Malumbres, M.; Barbacid, M. Mammalian cyclin-dependent kinases. Trends Biochem. Sci. 2005, 30, 630-641.

18. Malumbres, M.; Harlow, E.; Hunt, T.; Hunter, T.; Lahti, J.M.; Manning, G.; Morgan, D.O.; Tsai, L.-H.; Wolgemuth, D.J. Cyclind-Dependent kinases: A family portrait. Nat. Cell Biol. 2009, 11, 1275-1276.

19. Carassou, P.; Meijer, L.; le Moulec, S.; Aoun, J.; Bengrine-Lefevre, L. Cell-Cycle and molecular targets: CDK inhibition. Bull. Cancer 2012, 99, 163-171.

20. Malumbres, M.; Barbacid, M. Cell cycle, CDKs and cancer: A changing paradigm. Nat. Rev. Cancer 2009, 9, 153-166.

21. Meijer, L. The cell division cycle and its regulation. Bull. Cancer 2006, 93, 41-53.

22. Borgne, A.; Golsteyn, R.M. The role of cyclin-dependent kinases in apoptosis. Prog. Cell Cycle Res. 2003, 5, 453-459.

23. Garriga, J.; Grana, X. Cellular control of gene expression by T-type cyclin/CDK9 complexes. Gene 2004, 337, 15-23.

24. Cruz, J.; Tsai, L.H. CDK5 deregulation in the pathogenesis of Alzheimer's disease. Trends Mol. Med. 2004, 10, 452-458.

25. Sadleir, K.R.; Vassar, R. CDK5 protein inhibition and A $\beta 42$ increase BACE1 protein level in primary neurons by a post-transcriptional mechanism: Implications of CDK5 as a therapeutic target for Alzheimer disease. J. Biol. Chem. 2012, 287, 7224-7235. 
26. Kitani, K.; Oguma, S.; Nishiki, T.-I.; Ohmori, I.; Galons, H.; Matsui, H.; Meijer, L.; Tomizawa, K. A CDK5 inhibitor enhances the induction of insulinsecretion by exendin-4 both in vitro and in vivo. J. Physiol. Sci. 2007, 54, 235-239.

27. Knockaert, M.; Greengard, P.; Meijer, L. Pharmacological inhibitors of cyclin dependent kinases. Trends Pharmacol. Sci. 2002, 23, 417-425.

28. Graeser, R.; Wernli, B.; Franklin, R.M.; Kappes, B. Plasmodium falciparum protein kinase 5 and the malarial nuclear division cycles. Mol. Biochem. Parasitol. 1996, 82, 37-49.

29. Bracchi-Ricard, V.; Barik, S.; Delvecchio, C.; Doerig, C.; Chakrabarti, R.; Chakrabarti, D. PfPK6, a novel cyclin-dependent kinase/mitogen-activated protein kinase-related protein kinse from Plasmodium falciparum. Biochem. J. 2000, 347, 255-263.

30. Li, J.L.; Robson, K.J.; Chen, J.L.; Targett, G.A.; Baker, D.A. Pfmrk, a MO15-related protein kinase from Plasmodium falciparum. Gene cloning, sequence, stage-specific expression and chromosome localization. Eur. J. Biochem. 1996, 241, 805-813.

31. Li, Z.; le Roch, J.A.; Geyer, C.L.; Woodard, S.T.; Prigge, J.; Koh, C.; Doerig, N.C. Waters, influence of human p16(INK4) and p21 (CIP) on the in vitro activity of recombinant Plasmodium falciparum cyclin-dependent protein kinases. Biochem. Biophys. Res. Commun. 2001, 288, 1207-1211.

32. Le Roch, K.; Sestier, C.; Dorin, D.; Waters, N.; Kappes, B.;Chakrabarti, D.; Meijer, L.; Doerig, C. Activation of a Plasmodium falciparum cdc-2related kinase by heterogenous p25 and cyclin H: Functional characterization of a P. falciparum cyclin homologue. J. Biol. Chem. 2000, 275, 8952-8958.

33. Wiese, M. Leishmania MAP kinases-Familiar proteins in an unusual context. Int. J. Parasitol. 2007, 37, 1053-1062.

34. Woodward, C.L.; Li, Z.; Kathcart, A.K.; Terrell, J.; Gerena, L.; Lopez-Sanchez, M.; Kyle, D.E.; Bhattacharjee, A.K.; Nichols, D.A.; Ellis, W.; et al. Oxindole-Based compounds are selective inhibitors of Plasmodium falciparum cyclin dependent protein kinases. J. Med. Chem. 2003, 46, 3877-3882.

35. Holton, S.; Merckx, A.; Burgess, D.; Doerig, C.; Noble, M. Structures of P. falciparum PfPK5 test the CDK regulation paradigm and suggest mechanisms of small molecule inhibition. Structure 2003, 11, 1329-1337.

36. Bhattacharjee, A.K.; Geyer, J.A.; Woodard, C.L.; Kathcart, A.K.; Nichols, D.A.; Prigge, S.T.; Li, Z.; Mott, B.T.; Waters, N.C. A three-dimensional in silico pharmacophore model inhibition of Plasmodium falciparum cyclin-dependent kinases and discovery of different classes of novel Pfmrk specific inhibitors. J. Med. Chem. 2004, 47, 5418-5426.

37. Geyer, J.A.; Keenan, S.M.; Woodard, C.L.; Thompson, P.A.; Gerena, L.; Nichols, D.A.; Gutteridge, C.E.; Waters, N.C. Selective inhibition of Pfmrk, a Plasmodium falciparum CDK, by antimalarial 1,3-diaryl-2-propenone. Bioorg. Med. Chem. Lett. 2009, 19, 1982-1985.

38. Woodard, C.L.; Keenan, S.M.; Gerena, L.; Welsh, W.J.; Geyer, J.A.; Waters, N.C. Evaluation of broad spectrum protein kinase inhibitors to probe the architecture of the malarial cyclin dependent protein kinase Pfmrk. Bioorg. Med. Chem. Lett. 2007, 17, 4961-4966.

39. Legraverend, M.; Grierson, D.S. The purines: Potent and versatile small molecule inhibitors and modulators of key biological targets. Bioorg. Med. Chem. 2006, 14, 3987-4006. 
40. Haystead, T.A. The purinome, a complex mix of drug and toxicity targets. Curr. Top. Med. Chem. 2006, 6, 1117-1127.

41. Meijer, L.; Raymond, E. Roscovitine and other purines as kinase inhibitors. From starfish oocytes to clinical trials. Acc. Chem. Res. 2003, 36, 417-425.

42. Bach, S.; Knockaert, M.; Reinhardt, J.; Lozach, O.; Schmitt, S.; Baratte, B.; Koken, M.; Coburn, S.P.; Tang, L.; Jiang, T.; et al. Roscovitine targets, protein kinases and pyridoxal kinase. J. Biol. Chem. 2005, 280, 31208-31219.

43. Brain, J.; Plater, L.; Elliott, M.; Shpiro, N.; Hastie, C.J.; Mac Lauchlan, H.; Klevernic, I.; Arthur, J.S.; Alessi, D.R.; Cohen, P. The selectivity of protein kinase inhibitors: A further update. Biochem. J. 2007, 408, 297-315.

44. Oumata, N.; Bettayeb, K.; Ferandin, Y.; Demange, L.; Lopez-Giral, A.; Goddard, M.-L.; Myriabthopoulos, V.; Mikros, E.; Flajolet, M.; Greengard, P.; et al. Roscovitine-derived, dual-specificity inhibitors of cyclin-dependent kinases and casein kinases 1. J. Med. Chem. 2008, $51,5229-5242$.

45. Demange, L.; Nait Abdellah, F.; Lozach, O.; Ferandin, Y.; Gresh, N.; Meijer, L.; Galons, H. Potent inhibitors of CDK5 derived from roscovitine: Synthesis, biological evaluation and molecular modelling. Bioorg. Med. Chem. Lett. 2013, 23, 125-131.

46. Demange, L.; Lozach, O.; Ferandin, Y.; Hoang, N.-T.; Meijer, L.; Galons, H. Synthesis and evaluation of new potent inhibitors of CK1 and CDK5, two kinases involved in Alzheimer's disease. Med. Chem. Res. 2013, 22, 3247-3258.

47. Demange, L.; Oumata, N.; Quinton, J.; Bouaziz, S.; Lozach, O.; Meijer, L.; Galons, H. Synthesis of 6-pyridylaminopurines. Heterocycles 2008, 75, 1735-1743.

48. Surry, D.S.; Buchwald, S.L. Selective palladium-catalyzed arylation of ammonia: Synthesis of anilines as well as symmetrical and unsymmetrical di- and triarylamines. J. Am. Chem. Soc. 2007, 129, 10354-10355.

49. Tang, L.; Li, M.-H.; Cao, P.; Wang, F.; Chang, W.-R.; Bach, S.; Reinhardt, J.; Ferandin, Y.; Galons, H.; Wan, Y.; et al. Crystal structure of pyridoxal kinase in complex with roscovitine and derivatives. J. Biol. Chem. 2005, 280, 31220-31229.

50. Otyepka, M.; Krystof, V.; Havlicek, L.; Siglerova, V.; Strnad, M.; Koca, J. Docking-Based development of purine-like inhibitors of cyclin-dependent kinase-2. J. Med. Chem. 2000, 43, 2506-2513.

51. Dhariwala, F.A.; Rajadhyaksha, M.S. An unusual member of the Cdk family: Cdk5. Cell. Mol. Neurobiol. 2008, 28, 351-369.

52. Utreras, E.; Futatsugi, A.; Rudrabhatla, P.; Keller, J.; Iadarola, M.J.; Pant, H.C.; Kulkarni, A.B. Tumor necrosis factor- $\alpha$ regulates cyclin-dependent inase 5 activity during pain signaling through transcriptional activation of p35. J. Biol. Chem. 2009, 284, 2275-2284.

53. Wei, F.-Y.; Nagashima, K.; Ohshima, T.; Saheki, Y.; Lu, Y.-F.; Matsushita, M.; Yamada, Y.; Mikoshiba, K.; Seino, Y.; Matsui, H.; et al. Cdk5-Dependent regulation of glucose-stimulated insulin secretion. Nat. Med. 2005, 11, 1104-1108. 
54. Heathcore, D.A.; Patel, H.; Kroll, S.H.B.; Hazel, P.; Periyasamy, M.; Alikian, M.; Kanneganti, S.K.; Jogelakar, A.S.; Schreiper, B.; Barbazanges, M.; et al. A novel pyrazolo[1,5-a]pyrimidine is a potent inhibitor of cyclin-dependent protein kinases 1,2 and 9, which demonstrates antitumor effects in human tumor xenografts following oral administration. J. Med. Chem. 2010, 53, 8508-8522.

55. Laha, J.K.; Zhang, X.; Qiao, L.; Liu, M.; Chatterjee, S.; Robinson, S.; Kosic, K.S.; Cuny, G.D. Structure-activity relationship study of 2,4-diaminothiazoles as Cdk5/p25 kinase inhibitors. Bioorg. Med. Chem. Lett. 2011, 21, 2098-2101.

56. Shiradkar, M.; Thomas, J.; Kanase, V.; Dighe, R. Studying synergism of methyl linked cyclohexyl thiophenes with triazole: Synthesis and their cdk5/p25 inhibition activity. Eur. J. Med. Chem. 2011, 46, 2066-2074.

57. Flajolet, M.; He, G.; Heiman, M.; Lin, A.; Nairn, A.C.; Greengard, P. Regulation of Alzheimer's disease amyloid-beta formation by casein kinase I. Proc. Natl. Acad. Sci. USA 2007, 104, 4159-4164.

58. Meijer, L.; Thunnissen, A.M.; White, A.M.; Garnier, M.; Nikolic, M.; Tsai, L.H.; Walter, J.; Cleverley, K.E.; Salinas, P.C.; Wu, Y.Z.; et al. Inhibition of the cyclin dependent kinases, GSK-3beta and CK1 by hymenialdisine, a marine sponge constituent. Chem. Biol. 2000, 7, 51-63.

59. Perez, D.I.; Gil, C.; Martinez, A. Proteine kinases CK1 and CK2 as new targets for neurodegenerative diseases. Med. Res. Rev. 2011, 31, 924-954.

60. Wegiel, J.; Gong, C.X.; Hwang, Y.W. The role of DYRK 1A in neurodegenerative diseases. FEBS J. 2011, 278, 239-245.

61. Smith, B.; Medda, F.; Gokhale, V.; Dunckley, T.; Hulme, C. Recent advances in the design, synthesis, and biological evaluation of selective DYRK1A inhibitors: A new avenue for a disease modifying treatment of Alzheimer's. ACS Chem. Neurosci. 2012, 3, 857-872.

62. Dedbab, M.; Carreaux, F.; Renault, S.; Soundararajan, M.; Fedorov, O.; Filippakopoulos, P.; Lozach, O.; Babault, L.; Tahtouh, T.; Baratte, B.; et al. Leucettines, a class of potent inhibitors of cdc2-like kinases and dual specificity, tyrosine phosphorylation regulated kinases derived from the marine sponge leucettamine B. Modulation of alternative pre-RNA splicing. J. Med. Chem. 2011, 54, 4172-4186.

63. Tahtouh, T.; Elkins, J.M.; Filippakopoulos, P.; Soundarararjan, M.; Burgy, G.; Durieu, E.; Cochet, C.; Schmid, R.S.; Lo, D.C.; Delhommel, F.; et al. Selectivity, co-crystal structures and neuroprotective properties of Leucettines, a family of protein kinase inhibitors derived from the marine sponge alkaloid Leucettamine B. J. Med. Chem. 2012, 55, 9312-9330.

64. Neagoie, C.; Vedrenne, E.; Buron, F.; Mérour, J.Y.; Rosca, S.; Bourg, S.; Lozach, O.; Meijer, L.; Baldeytou, B.; Lansiaux, A.; et al. Synthesis of chromeno[3,4-b]indoles as lamellarin D analogs: A novel DYRK 1A inhibitor class. Eur. J. Med. Chem. 2012, 49, 379-396.

65. Beniddir, M.A.; le Borgne, E.; Iorga, B.I.; Loaec, N.; Lozach, O.; Meijer, L.; Awang, K.; Litaudon, M. Acridone alkaloids from glycosmis chlorosperma as DYRK1A inhibitors. J. Nat. Prod. 2014, 77, 1117-1122.

66. Dehbi, O.; Tikad, A.; Bourg, S.; Bonnet, P.; Lozach, O.; Meijer, L.; Aadil, M.; Akssira, M.; Guillaumet, G.; Routier, S. Synthesis and optimization of an original V-shaped collection of 4-7-disubstituted pyrido[3,2-d]pyrimidines as CDK5 and DYRK1A inhibitors. Eur. J. Med. Chem. 2014, 80, 352-363. 
67. Pan, Y.; Wang, Y.; Bryant, S.H. Pharmacophore and 3D-QSAR characterization of 6-arylquinazolin-4-amines as cdc-2 like kinase $4(\mathrm{Clk} 4)$ and dual specificity tyrosine phosphorylation-regulated kinase 1A (Dyrk1A) inhibitors. J. Chem. Inf. Model. 2013, 53, 938-947.

68. Elagawany, M.; Ibrahim, M.A.; Ali Ahmed, H.E.; El-Etrawy, A.S.; Ghiaty, A.; Abdel-Samii, Z.K.; El-Feky, S.A.; Bajorath, J. Design, synthesis, and molecular modeling of pyridazinone and phthalazinone derivatives as protein kinases inhibitors. Bioorg. Med. Chem. Lett. 2013, 23, 2007-2013.

69. Desjardins, R.E.; Canfield, C.J.; Haynes, J.D.; Chulay, J.D. Quantitative assessment of antimalarial activity in vitro by a semiautomated microdilution technique. Antimicrob. Agents Chemother. 1979, 16, 710-718.

70. Harmse, L.; van Zyl, R.; Gray, N.; Schultz, P.; Leclerc, S.; Meijer, L.; Doerig, C.; Havlik, I. Structure-Activity relationships and inhibitory effects of various purine derivatives on the in vitro growth of Plasmoduim falciparum. Biochem. Pharmacol. 2001, 62, 341-348.

71. Too, K.; Brown, D.M.; Bongard, E.; Yardley, V.; Vivas, L.; Loakes, D. Anti-Malarial activity of $\mathrm{N}^{6}$-modified purine analogues. Bioorg. Med. Chem. 2007, 15, 5551-5562.

72. Legraverend, M.; Ludwig, O.; Bisagni, E.; Leclerc, S.; Meijer, L.; Giocanti, N.; Sadri, R.; Favaulon, V. Synthesis and in vitro evaluation of novel 2,6,9-trisubstituted purines acting as cyclin-dependent kinase inhibitors. Bioorg. Med. Chem. 1999, 7, 1281-1293.

73. Bettayeb, K.; Oumata, N.; Echalier, A.; Ferandin, Y.; Endicott, J.; Galons, H.; Meijer, L. CR8 a potent and selective, roscovitine-derived inhibitor of cyclin-dependent kinases. Oncogene 2008, 27, 5797-5807.

74. Reinhardt, J.; Ferandin, Y.; Meijer, L. Purification of GSK-3 by affinity chromatography on immobilized axin. Protein Expres. Purif. 2000, 20, 394-404.

75. Kaddouri, H.; Nakache, S.; Houzé, S.; Mentré, F.; le Bras, J. Drug susceptibility of Plasmodium falciparum clinical isolates from africa using plasmodium lactate dehydrogenase immunodetection assay and inhibitory emax model for precise $\mathrm{IC}_{50}$ measurement. Antimicrob. Agents Chemother. 2006, 50, 3343-3349.

76. ICEstimator Version 1.2. Available online: http://www.antimalarial-icestimator.net (accessed on 22 September 2014).

Sample Availability: Samples of the are not available.

(C) 2014 by the authors; licensee MDPI, Basel, Switzerland. This article is an open access article distributed under the terms and conditions of the Creative Commons Attribution license (http://creativecommons.org/licenses/by/3.0/). 